Portland State University

PDXScholar

\title{
The relationship between self-concept and responses of others during a marital crisis
}

\author{
Kathryn Ann Farr \\ Portland State University
}

Follow this and additional works at: https://pdxscholar.library.pdx.edu/open_access_etds

Part of the Family, Life Course, and Society Commons

Let us know how access to this document benefits you.

\section{Recommended Citation}

Farr, Kathryn Ann, "The relationship between self-concept and responses of others during a marital crisis" (1975). Dissertations and Theses. Paper 1980.

https://doi.org/10.15760/etd.1979

This Thesis is brought to you for free and open access. It has been accepted for inclusion in Dissertations and Theses by an authorized administrator of PDXScholar. Please contact us if we can make this document more accessible: pdxscholar@pdx.edu. 
AN ABSTRACT OF THE THESIS OF Kathryn Ann Farr for the Master of Arts in Sociology presented. February 28, 1975.

Title: The Relationship Between Self-Concept and Responses of Dthers During a Marital Crisis.

APPROVED BY NEMBERS OF THE THESIS COMMITTEE:

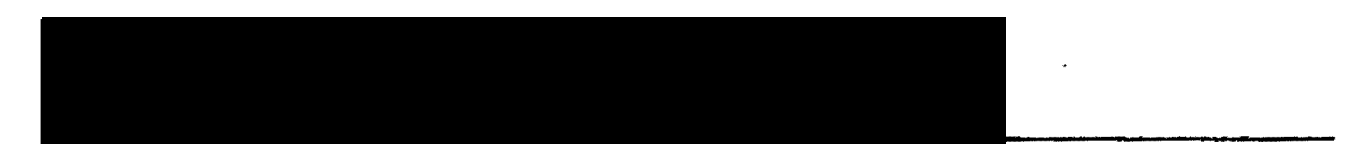
Nona Glapermaly

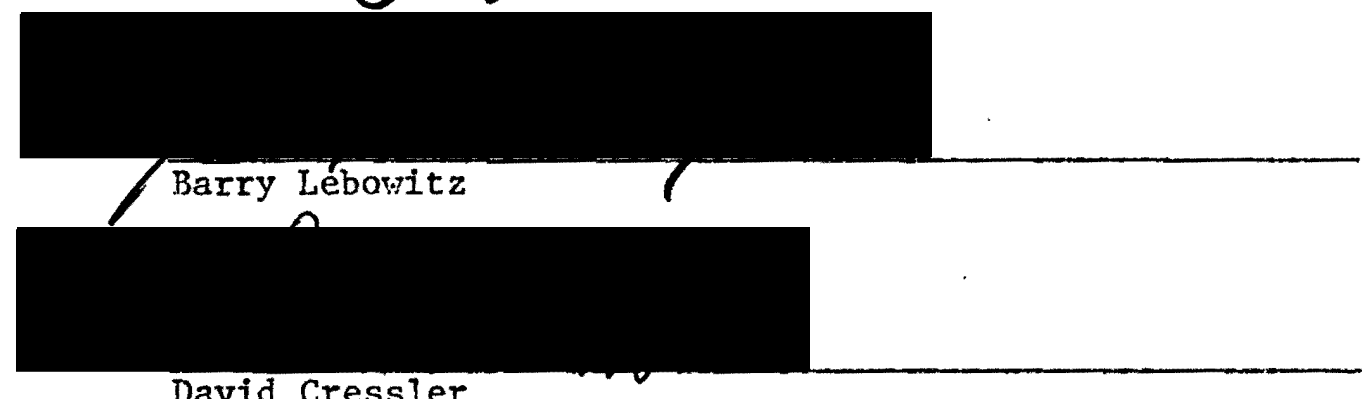

Symbolic interaction theory indicates that an individual's selfconcept is related to the way in which the individual perceives others as responding to him/her. Although this theory is widely accepted in social psychology, it has been given 1ittle empirical attention. In this study a typological model was developed in an empirical examination of the relationship between self-concept and responses of others during marital crisis. Self-concept was deftned as the organization of qualities (roles, social-psychological feelings) that an individual assigns to himself/ 
herself. Kinds of qualities were described, and social-psychological feelings about self were examined on a positive to negative continuum. Responses of others were defined as the kind and amount of support perceived by respondents as being given to them by others (relatives, friends, dates, husband, children) during marital separation. Kinds of support were described, and amount of support was examined on a positive to negative continuum. The typological model was developed from intervietws with fifteen white, middle and upper middle class women between the ages of 25 and 35 who were separated but not legally divorced from their husbands. The interviews consisted of two parts: 1) an in-depth, open-ended interview between respondent and researcher aided by àguide; 2) a standardized questionnalre in which respondents rated their perceptions of self and responses of others on a positive to negative scale. Five types of selfconcept/responses of others relationships were found and described. These types were labeled: 1) New Lifers; 2) Revisors; 3) Adaptors; 4) Endurers; 5) Mourners. In all types a positive relationship was found between selfconcept and responses of others. This positive relationship was most clearly indicated in the extreme types, i.e., the New Lifers were characterized by a high positive self-concept and high, positive responses from others, whereas the Mourners were characterized by a high negative self-concept and lack of or negative responses from others. In addition to the quality and quantity of support, five other factors were found to be related to self-concept during marital separation. These factors, incorporated into the model as properties of the types, were: 1) who initiated the separation; 2) the presence or absence of an understanding of what led to the marital dissolution; 3) how the separation was defined by the 
respondent; 4) self-concept and situation prior to separation;

5) commitment to marriage. Also, certain common reactions to dissolution were reported by the women in all types: 1) loneliness; 2) fear or anxiety; 3) growing awareness of capabilities; 4) changing emotions; 5) feelings of social isolation; 6) the desire for close, intimate opposite-sex relationships, These commonalities were discussed, and their implications for further research were set forth. 
THE REIATIONSHIP BETWEEN SELF-CONCEPT ANT RESPONSES

OF OTHERS DURING A MARITAL CRISIS

by

KATHRYN ANN FARR

A thesis submitted in partial fulfillment of the requirements for the degree of

MASTER OF ARTS

in

SOCIOLOGY

Portland State University

1975 
TO THE OFFICE OF GRADUATE STUDIES AND RESEARCH:

The members of the Comnttee approve the thesis of

Kathryn Ann Farr presented February 28, 1975.

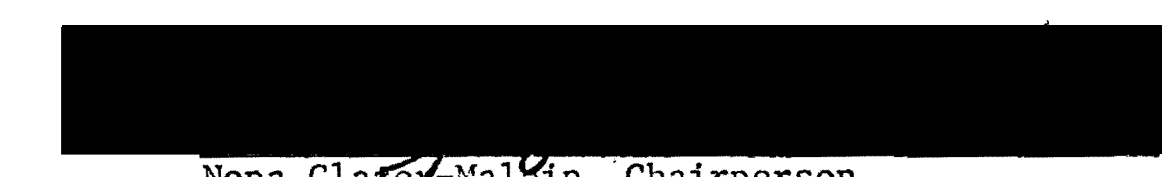

Nona Glat-MalYin, Chairperson

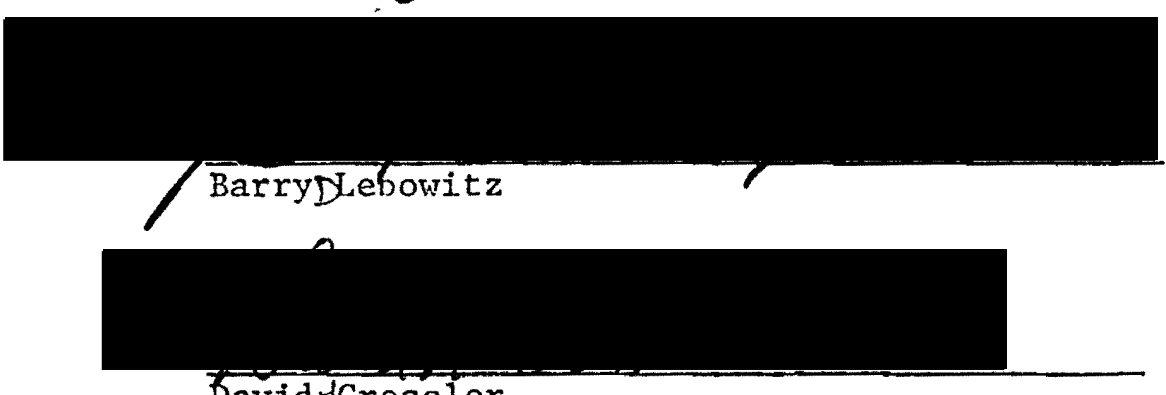

David

APPROVED

Robert N. Shotola, Chairman, Department of Sociology

David Clark, Dean of Graduate Studies and Research 


\section{CHAPTER}

I INTRODUCTION . . . . . . . . . . . . . 1

II THEORETICAL BACKGROUND. . . . . . . . . . 3

The Situational and Cultural Setting . . . . 3

Self-Concept ............... 5

Responses of Others. . . . . . . . . 6

The Relationship Between Self-Concept and

Responses of Other........... 7

III METHODOLOGY . . . . . . . . . . . 11

The Respondents. . . . . . . . . . 12

The Interviews . ........... . 16

Combining Qualitative and Quantitative Data. . 19

Interview Guide. . . . . . . . . 20

Standardized Questionnaire . . . . . . 22

Characteristics of Individual Respondents . . 27.

IV THE POSITIVE RELATIONSHIP BETWEEN SELF-CONCEPT

AND RESPONSES OF OTHERS . . . . . . . . . 29

V THE MODEL . . . . . . . . . . . 36

Responses of Others: Support : . . . . . 37

Additional Properties of the S-C:RO Types. . 40

Types of S-C:RO Relationships . . . . . 44

New Lifers

Revisors

Adaptors

Endurers

Mourners 
Discussion of Types . . . . . . . 61

Self-Concept

Responses of Others

Additional Properties

Relatives

Children

How Long Married

VI IMPLICATIONS AND SUGGESTIONS FOR FURTHER RESEARCH

71

Modifying the Model ............ 71

The types

Over-Time Studies

Perceptions of Others

Limits of the Model's Applicabilfty . . . .

The Respondents

The Situation

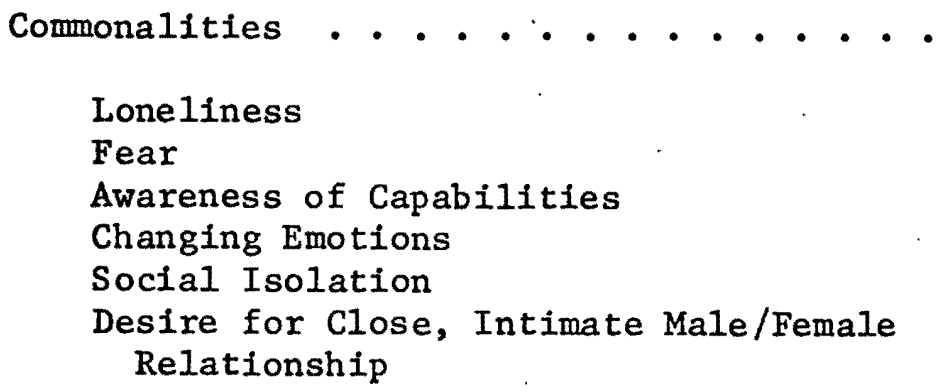

Loneliness

Fear

Awareness of Capabilities

Changing Emotions

Social Isolation

Desire for Close, Intimate Male/Female Relationship

Concluding Remarks . . . . . . . . . 84 


\section{LIST OF TABLES}

PAGE

I Standardized Questionnaire Data . . . . . . . . 26

II A Typology of the S-C:RO Relationship . . . . . . 39 


\section{CHAPTER I}

\section{INTRODUCTION}

A basic tenet of symbolic interaction theory is that the individual learns a self-concept through interaction with others in a given situational and cultural setting. According to Videbeck:

The view that one's self-conception is learned from the reactions of other individuals to him [her] has achieved wide acceptance in social psychology today, but is implications have not been much exploited empirically (Videbeck, 1960: 35I).

The purpose of this study was to build a typological model of the relationship between self-concept and the perceived responses of others. In order to build such a model, I decided to gather data by interviews with a specific category of people, each of whom were experiencing a specific situation. These criteria were met by interviewing white, middle or upper middle class American women between the ages of 25 and 35 who were separated but not legally divorced from their husbands. By limiting my focus in this way, I was able to examine the self-concept $(S-C)$ : responses of other (RO) relationship of simflar people in a similar situation. Thus, in a rough way, differences in the S-C:RO relationship which might have been due to differences in sex, age, social class, ethnicity and crisis situations were lessened. In addition, the selection of this study group allowed me to gather information on the effects of a marital crisis, i.e., separation, on white, niddle class, American women in the 25-35 age bracket. 
Analysis of the data led to the development of a typological model In which five types of S-C:RO relationships were described. The model also included a description of the way in which other factors were related to the S-C:RO types. These factors were: 1) who inftiated the separation; 2) an understanding of what led to the separation; 3) the way in which respondents defined the separation; 4) self-concept and situation prior to separation; 5) commitment to marriage.

The typological model, therefore, provided a framework within which 1) the global S-C:RO relationship suggested by symbolic interaction theory could be examined in greater detail; 2) the S-C:RO relationship could be examined in a crisis situation; 3) the social-psychological effects of marital separation on the described category of people could be examined. Although the findings of the study cannot at this point be generalized beyond the separated women who were interviewed, the typological model can be useful in further studies, including (but not exclusively) those of marital crisis. The possibility of generating a formal model from an exploratory substantive model has been set forth by Glaser and Strauss :

Since substantive theory is grounded in research on one particular substantive area . . . it might be taken to apply only to that specific area. A theory at such a conceptual level, however, may have important general implications and relevance, and become almost automatically a springboard or stepping stone to the deve1opment of a grounded formal theory (Glaser and Strauss, 1967: 79).

Therefore, while it is important that the limits of the model's applicability be delineated, it is of primary importance that implications of the study and suggestions for further research be set fort. This was done in the final chapter of the thesis. 
CHAPTER II

THEORETICAL BACKGROUND

THE SITUATIONAL AND CULTURAL SETTING

The relationship between self-concept and the responses of others was examined during one kind of marital crisis, that which had resulted in the separation of the mates. In Goode's study of divorce he found that the time of greatest disturbance or crisis in the divorce process was the time of physical separation (Goode, 1956: 187). Waller and Hill suggest that "...the crisis of separation ... is usually severe. The business of liquidating a menage is sorry enough at best; when there is added to it the severance of a meaningful relationship, it is often traumatic in the extreme." (Waller and Hill, 1951:485) From this statement it appears that there are two facets of the separation crisis: 1) the crisis of the structural dissolution of a household;2) the crisis of the interpersonal dissolution of a relation. A marital crisis which results in physical separation is a transition or turning point in the 11fe of an individual. Berger and Kellner indicate that in American society, once marriage has taken place, the marital role becomes a primary source of identity (Berger and Kellner, 1970). Thus, it appears that changing from the role of married man/woman to separated man/woman Involves a major transition in self-concept. In addition, although the roles of husband and wife are well-defined in American society, the role of separated mate is ambiguous (Goode, 1956). 
How to define one's self during a crisis situation appears to be problematic for an individual because a crisis requires some change or reorganization of an individual's patterned ways of living. According to Foote and Cottre11:

The development of identity in a person or a group, is established by the pattern of recurrence of related events . . . identity is the thread which unites episode to episode . . . there are many transitions and turning points, and each is a dramatic event, which may be appraised as news or as development . . (Foote and Cottre11, 1955: 16).

A crisis is a turning point in which this thread is broken. According to Sherif:

- . [the] stability of our status in these many respects forms the identity of our persons.- When this stability is obscured we are confused; when it is damaged we are deeply hurt; when the ties that bind us to a definite status are cut off we toss in a strange and hostile sea with uncertainty and distress (Sherif, 1936: 197).

American culture also places great importance upon interpersonal success in the marital relationship. The fallure of marriage is often viewed as an indication of the failture of the married persons to successfully interact and maintain their relationship. In our society, according to. Bohannan: "The sense of fallure, which many divorced persons experience, is hard to relieve; only success can overcome it." (Bohannan, 1970: 12) It is assumed that when failure does occur, the processes that follow are essentially negative (Goode, 1956:5). There is some evidence that marital success is more important for women than for men in American society. Traditionally women have been expected to gain their major satisfaction from their domestic roles, le.e, wife and mother. Thus, fallure in such roles could lead to personal trauma and psychological disorganization. While there is some indication that the cultural norms on marriage and dissolution of marriage are changing in American society (Bernard, 1970; 
Libby and Thitehurst, 1973; Bohannan, 1970), it appears that the traditional institution of marriage still has wide cultural support. Says Schwartz: ". . at least at the level of ideology (if not practice) the monogamous nuclear family model is still safely ensconced in the mainstream of American life." (Schwartz, 1973: 212)

In examining the self-concept of and responses of others to separated individuals, then, it is important to understand how the separated individual perceives norms on marriage and divorce, success and failure, personal growth and happiness both in his/her particular situation and in a wider cultural context. The way in which an individual defines the situation and the way in which he/she percetves others to define the situation would appear to be a factor worth investigation in the relationship between selfconcept and responses of others. In the words of Thomas:

Preliminary to any self-determined act of behavior there is always a stage of examination and deliberation which we may call the definition of the situation. And actually not only concrete acts are dependent on the definition of the situation, but gradually a whole life-policy and the personality of the individual himself follow from a serles of such definitions (Thomas, 1931: 41).

\section{SELF-CONCEPT}

In this study the definition of self-concept set forth by Kinch was used :

The self-concept is that organization of qualities that the individual attributes to himself. It should be understood that the word "qualities" is used in a broad sense to include both attributes that the individual might express in terms of adjectives (ambitious, intelligent) and also the roles he sees himself in (father, doctor, etc.) (Kinch, 1963: 233). This study focused on soclal-psychological feelings about self on a positive/negative continuum. While the focus of the study was on the 
individual's self-concept at a sepcific point in time, 1.e., during separation, I also attempted to collect information on the individual's perceptions of self prior to separation. This was done for two reasons. First, self-concept at a given time cannot be isolated from the biographIcal development of self-concept over time. Individuals begin to develop a self-concept at an early age through interaction with significant others, i.e., family members and friends. Initially, certain significant others are imposed on the individual and the definitions of these others are set forth for him/her as objective reality (Berger and Luckmann, 1967: 131). As the socialization process continues the circle of others with whom an Individual interacts widens. Thus, the development of self-concept is a continual process in which perceptions of self and perceptions of responses of others to self reinforce one another. Second, information on the Individual's self-concept prior to separation allowed me to estimate the impact of a crisis on the self-concept.

\section{RESPONSES OF OTHERS}

In this study, the others with whom an individual comes into contact were perceived as the individual's social network. In her work on family and social networks, Bott concluded that the social relationships of family members took the form of a network rather than of an organized group. "In a network the component external units do not make up a larger social whole; they are not surrounded by a common boundary." (Bott, 1957: 59) Thus, the responses of others to the separated individual may or may not be consistent with each other. These networks, according to Bott, are made up of friends, neighbors, relatives and particular social institutions (Bott, 1957: 159). In the present study the social network of the separated 
Individual included: 1) own relatives; 2) in-law relatives; 3) spouse;

4) children; 5) close friends of the individual; 6) friends the husband and wife had as a couple; 7) dates or opposite-sex relationships; 8) new friends since separation; 9) formal relationships, i.e., people with whom the individual comes into contact for some functional purpose. An examination was made of the separated individual's perceptions of responses to her as a separated person.

THE RELATIONSHIP BETWEEN SELF-CONCEPT AND RESPONSES OF OTHERS

Interaction theory which emphasizes the importance of the perceptions of responses of others in shaping self-concept is based in great part on the work of George Herbert Mead and Charles Horton Cooley. Mead viewed the development of self as a social process in which the responses of others provided the key to definitions and redefinitions an individual gave to his/her own person. For example:

(the self) arises in the process of social experience and activity, that is, develops in the given individual as a result of his relations to that process as a whole and to other individuals within that process (Mead, 1934: 135).

And likewise:

Since it is a social self, it is a self that is realized in its relationship to others. It must be recognized by others to have the very values which we want to have belong to it (Mead, 1934: 204).

Although Mead referred to the importance of the responses of others in the development of self-concept, upon close examination of his work it appears that he felt that perceptions of responses was more crucial than actual responses. An individual's reality is constructed in line with such perceptions. Mead saw the self as being made up of two parts, the "I" 
and the "me". The "I" was the response of the organism to the attitudes of others, and the "me" was the organized set of attitudes of others which one assumes (Mead, 1934: 175). Based upon this distinction, the "me" was the input (that which was perceived from others), and the "I" was the output (that which was given back to others). There was a third component of self, the "generalized other", defined as "the organized community of social groups which give to the individual his unity of self . ." (Mead, 1934: 154). The social development of self was said to take place in these stages:

At the first of these stages, the individual's self is constituted simply by an organization of the particular attitudes of other individuals toward-himself and toward one another in the specific social sets in which he participates with them. But at the second stage in the full development of the individual's self that self is constituted not only by an organization of these particular individual attitudes, but also by an organization of the social attitudes of the generalized other or the social group as a whole to which he belongs (Mead, 1934: 158).

Although Mead's conceptualization of the "I", the "me", and the "generalized other" is at times inconsistent and ambiguous, his committment to an explicit conceptualization of the relationship between self and others is clear. Cooley also supported the theory that self-concept was dependent upon the responses of others. According to him, the self-idea has three principal elements: ". . the imagination of our appearance to the other person; the imagination of his judgment of that appearance, and some sort of self-feeling..." (Cooley, 1902: 384). Cooley developed the concept of the "looking-glass self" to describe the process by which this interaction between self and others took place.

In a very large and interesting class of cases the social reference takes the form of a somewhat definite imagination of how one's self -- that is any idea he appropriates -appears in a particular mind, and the kind of self-feeling one has is determined by the attitude toward this attributed 
to that other mind. A social self of this sort might be called the reflected or looking glass self . . (Cooley, 1902: 183-184).

This concept refers to taking the role of the other in assessing and reassessing perceptions of self. Thus, the development of self is a continual process of interaction between the self and perceptions of the responses of others to the self.

In recent years, other social scientists have added to the theories set forth by Mead and Cooley. Blumer noted that human beings are acting rather than reacting agents. Thus, he emphasized the fact that individuals must interpret or define the responses of others. He said: "Self-indication is a moving communicative process in which the individual notes things, assesses them, gives them a meaning, and decides to set on the basis of the meaning." (Blumer, 1962: 141) Goffman also emphasized the acting nature of the individual. Since the definition of self is dependent upon the responses of others, individuals, according to Goffman, attempt to present their self to others in particular ways in order to get particular responses (Goffman, 1959). The interaction process between self and others is supported in Goffman's analysis.

Kinch has also focused on interaction in his formalized theory of self-concept. His theory is based upon the interaction between four variables: 1) the individual's self-concept; 2) the individual's perceptions of the responses of others toward him/her; 3) the actual responses of others toward him/her; 4) the individual's behavior (Kinch, 1963). Kinch concluded that: "The individual's conception of himself emerges from social interaction and, in turn, guides or influences the behavior of that individual." (Kinch, 1963: 482) If individuals are acting rather than reacting agents, and if individuals build a self-concept from the interaction between self and others, such a building process 
can be problematic. In Bolton's words:

By "problematic" is meant that the outcome of the contacts of . . Individuals is not mechanically predetermined either by the relation of their personality characteristics or the institutional patterns providing the context for the development of the relation -- though these are both certainly to be taken into account -- but that the outcome is an endproduct of a sequence of interaction . . (Bolton, 1961: 41).

In addition to the basic premise that self-concept is learned through Interaction with others in a given situational and cultural setting, Interaction theory holds that 1) individuals, as acting agents, build their self-concepts; 2) the process of building a self-concept is problematic.

Several studies of college students have attempted to test the theory that the self-concept was related to the perceptions of the responses of others. In separate, experimental studies, Videbeck, Manis and Miyamoto and Dornbusch found a relationship between self-attitudes and attitudes of others (Videbeck, 1960; Manis, 1955; Miyamoto and Dornbusch, 1956). In the present study, data were collected in the field using adult women in marital crisis as respondents. As far as the writer knows, no studies of the relationship between women's self-concept and the responses of others during marital crisis have been done. 
CHAPTER III

METHODOLOGY

In order to generate a. model to describe the relationship between self-concept and responses of others, data were gathered from two sources: 1) Iiterature relevant to the area of study; 2) interviews with separated women. Although there are substantial bodies of literature both on selfconcept and responses of others, and on marrlage, there is a dirth of literature on separation. Therefore, the model development relied heavily on the data collected from interviews with respondents. The findings of the study were best expressed through the development and illustration of types describing different relationships between self-concept and responses of others based on the interviews. This was compatible with the exploratory nature of the study. The methodology was based upon the work of Glaser and Strauss as presented in The Discovery of Grounded Theory. According to the authors:

In discovering theory, one generates conceptual categories or their properties from evidence; then the evidence from which the category emerged is used to illustrate the concept . . . The evidence may not necessarily be accurate beyond a doubt (nor is it even in studies concerned only with accuracy), but the concept is undoubtedly a relevant theoretical abstraction about what is going on in the area studies (Glaser and Strauss, 1967: 23).

Glaser and Strauss' methodology entalls a good deal of flexibility. Their research procedure proscribes the analysis of data as they are being collected as well as the continual re-thinking of categories and pertinent interview questions and observations. Nevertheless, the research process is structured. In this case, each interview had a clear, pre-determined 
focus on the relationship between self-concept and the responses of others during marital separation. New questions were added to interviews or old ones modified in accordance with analysis of preceding interviews, but the pre-determined focus was the essential guide for each interview. Bolton's study of mate selection served as a precedent for this type of model building. Bolton gathered data on twenty recently married couples which he used to generate process categories by which mate selection as the development of a relationship could be examined. Five categories or types emerged from the data. To these he gave the labels: 1) personality meshing developmental process; 2) identity clarification developmental process; 3) relation centered developmental process; 4) pressure and intrapersonal centered developmental process; 5) expediency centered developmental process (Bolton, 1961: 238). He then used his data to define the properties of these categories. Perceptions of couples who most nearly approximated each type were used to illustrate the five processes of mate selection as the development of a relationship.

Although the primary focus of the study was on the relationship between self-concept and responses of others, the data indicated that there were a number of factors (in addition to responses of others) which were related to self-concept during separation. An examination of these factors was included in the development of the model.

\section{THE RESPONDENTS}

The respondents were selected by the researcher on the following criteria: 1) race, soclal class, sex and age: white, middle and uppermiddle class women between the ages of 25 and 35 ; 2) marital status: currently physically separated from their mate but not legally divorced; 
3) verbal and conceptual skills: ability to express their perceptions regarding self-concept and responses of others during marital crisis; 4) willingness to participate in the study: cooperative and open in their respondent role. The use of a specifically-defined category of respondents enables the researcher to focus on differences in the self-concept/responses of others relationship rather than differences in the statuses and skills of the respondents. In addition, the use of a specifically-defined category allowed me to gain some insight into the effects of separation on the self-concept of this particular category of people. The initial controls were supplemented by others upon completion of the interviewee selection. The fifteen respondents had the following characteristics: 1) they ranged from 26 to 34 years of age; 2) they were predominantly college-educated; eleven graduated from college; four completed from one to three years of college; eight were currently attending college (six at the graduate level and two at the undergraduate level; 3) although all had experienced a drop in income since separation, financial worries did not appear to be a major factor in adjustment to separation; 4) all were in their first marriage; 5) eleven women had children ranging in age from two to twelve living with them; all women with children had custody of the children. The results of the study and the implications of those results have to be limited to this category of people unt 11 further studies are done. Suggestions for comparative studies with other kinds of people are discussed in Chapter VI.

Al1 respondents were separated from their husbands at the time of the interview, and all but one were living alone or with their children (one woman was living with her mother and daughter). The length of marriage 
ranged from five to thirteen years, and the length of separation ranged from two to ten months. All but two of the women were separated for the first time; the two exceptions were separated from the same husband for the second time. All women were considering divorce, and in nine cases, the couples had filed for divorce.

None of the women in this study was interviewed when the physical act of separating was taking place. In support of prior evidence that the crisis of marital breakdown may be most severe at the time of the separation (Waller and Hill, 1938; Goode, 1956), the women Indicated that the act of separating was stressful and traumatic emotionally. Although it appeared from the data that separation could be stressful and traumatic throughout its duration, it must be remembered that the respondents vere interviewed after the inftial crisis. There was an adjustment period of at least two months before the interview took place. Illustrative of feelings at the time of initial separation are the following statements:

When we first separated I was at a point where I realized that something had to change very drastically, or I was finally just going to go ahead and kill myself or absolutely break up. Something had to change drastically. \#8

The separation was very, very hard for me at first. I did a lot of not eating, crying sort of things. I'm trying to think when I stopped just crying all day long; about two or three weeks, it seems like, I was just really unhappy. "

Right after he left I called (mental health clinic) and got no response. I felt like I could have committed suicide and no one would have noticed. I called family counseling -- nothing. They could get me in in about three weeks. At the time I thought I was not going to make it. Now I look back on it, and I think how could I have ever felt that way? \#13

At first I was upset; I've never felt that way before, kind of like I didn't have control of myself. I'd cry alot. \#15

All respondents approached were willing to participate in the study. At the beginning of the selection process I approached potential respondents 
with some trepidation, thinking that they might be unwilling to discuss their feelings about the breakdown of their marriage openly. As the selection process proceeded, however; I was impressed by the candor and ease with which the women expressed their perceptions of their separations. The interviews required very little probing or prodding from me; the women simply had a lot to say and said it. At the same time they atterided to the focus to which I directed them and rarely "wandered off the subject". I also found the respondents to be articulate and definitive in giving me the kind of information I was seeking. The women reported that the crisis of separating had led them to a great deal of self-analysis and reflection, and that they had spent a great deal of time thinking about the kinds of questions that they were being asked in the interview. Perhaps this was influential in making the interviewing an easy and comfortable experience both for me and for the respondents.

Although the respondents appeared to be answering the questions honestly and candidly, the information given and the subsequent results of the study were based only on the perceptions of the respondents. The perceptions of others in the respondents' social networks may or may not have been consistent with the perceptions of the respondents. The reality with which this study was concerned was the reality as perceived by the separated women.

The study results may be biased since respondent selection was not random. In order to find respondents, I talked to friends, acquaintances, co-workers, etc., about the study, asking them if they knew of women who met the requirements for my respondent group. In this way I was given names of some potential respondents. From this beginning a 
"snowball" process emerged in which certain leads led to other leads. Thus, although respondents did not come from any one source, a few were known to each other.

A problem with which a researcher is faced in any study is the determination of how much data should be collected. Naturally this varies with the type and purpose of the study. According to Glaser and Strauss, data collection should stop when the researcher finds that he/she is no longer getting new information pertinent to the study.

The criterion for judging when to stop sampling the different groups pertinent to a category is the category's theoretical saturation. Saturation means that no additional data are being found whereby the sociologist can develop properties of the category (Glaser and Strauss, 1967: 61).

However, the problem of determining when this saturation point has arrived has not been adequately dealt with by Glaser and Strauss. The researcher is ultimately left to his/her own discretion. Other factors such as time, accessibility, and money may be infiuential in bringing the data collection process to an end. In this study fifteen interviews were conducted. I did feel that at this point enough information had been generated to adequately describe and illustrate types by which the relationship between self-concept and responses of others during separation could be closely examined. Although it appeared at this point that no new information was being added, the decision to stop interviewing was somewhat arbitrary, based in part on the limited time of the researcher.

\section{THE INTERVIEWS}

Since the purpose of the study was to generate rather than verify a mode1, it seemed Important to allow the respondents some freedom in expressing their perceptions. Therefore a considerable part of the 
Interview was open-ended. With the aid of the guide questions shown on pages 20 and 21 , I engaged the women in informal conversation focusing on self-concept and responses of others during separation. It has been suggested by Maccoby and Maccoby that unstructured, non-standardized interviews are best suited for exploratory studies (Maccoby and Maccoby, 1954). Goode and Hatt pointed out that the qualitative interview is more difficult to assess simply because of its non-standardization. However, they continued, in order to gain standardization, depth is often sacrificed. Thus, the qualitative interview, if properly analyzed, may get at deeper meaning (Goode and Hatt, 1952).

In order to aid in the analysis of the qualitative data, the nonstandardized interview was supplemented by 24 standardized questions in which respondents were asked to rate their perceptions of self-concept and responses of others on an intensity scale from seven to one. When asked how supportive relatives had been, for example, respondents were asked to select an answer ranging from very supportive to very nonsupportive. The choices were then given a numerical value ranging from seven to one for use in analysis.

In the standardized questionnaire, respondents were also asked questions about how close they were to others in their social network and how supportive these others had been to them since their initial separation. Since definitions of "close" and "supportive" were not provided by the researcher, the women were asked to describe briefly what the terms meant to them. These descriptions were simflar in all cases and consistent with what I had in mind when formulating the questions. The following examples were typical: 
Definitions of "close";

Able to be freely myself with someone. Share intimate thoughts and feelings with another. High trust level in relationship. 非

Being able to talk about all kinds of things from a shared viewpoint. Not judging one another, but accepting and really caring about one another. 33

Intimate; being able to communicate feelings; anger, happiness, etc. \#1

Willingness to open yourself up to a relationship, to give and receive freely without fear of criticism. \#13

Being able to talk freely and honestly to someone you like and respect. 非15.

Definitions of "supportive";

Non-judgmental attitude on part of supportive person. Supportive person also affirms the other's feelings, but also helps keep a perspective on reality. \#2

People who will 1isten to what I say and not be judgmental, expressing their belief in me. 非 3

Being there when you need them, i.e., someone to talk to; caring about you and how you are doing in 1ife. 非

Helpful, not judgmental. $\sharp 8$

Willing to help, be there when needed. $\$ 10$

People are behind you in what you do and decisions you make -they will back you. \#11

Summarizing these results, it appeared that to the respondent group the term "close" connoted intimacy, open communication, and sharing feelings, while the term "supportive" connoted non-judgmental acceptance, willingness to be there when needed, willingness to listen and understand. The terms, then, were interpreted as having social-psychological meaning (in contrast to financial support, support by taking care of the children, etc.). 
The interview guide which I used to direct the respondents in the open-ended part of the interview is given on pages 20 and 21 . The standardized questionnaire which I administered to the respondents in written form is presented on pages $22-25$. The coded results of the standardization questionnaires are given as raw data on page 26. As stated earlier, the results of the standardized questionnaire have been used only to aid in the qualitative interpretation of the entire interview. No statistical computations have been attempted due to the exploratory nature of the study and to the small sample size. However, it does seem pertinent to make some comments on the use of two methodologies to gain insight into the same problem, in this case the relationship between self-concept and responses of others during separation.

\section{COMBINING QUALITATIVE AND QUANTITATIVE DATA}

Accurate analysis of a lengthy, non-standardized interview depends upon the skills of the researcher. Even with a small respondent group, the researcher finds himself/herself with an overwhelming amount of data. Editing the data involves 1) selecting that material which is relevant to the focus of the study; 2) looking for covert meanings in that which is stated overtly; 3) integrating the material into a systematic analysis. Also, the structuring of a quantitative questionnaire is problematic. There is always the possibility that the questions and answers may be vague and misunderstood by respondents. The order in which questions and answers are presented may also influence the results (Carp, 1974). It has been found that respondents may rate themselves on a global type of question (e.g., how are you feeling now?) in a way which may seem 
higher than suggested by other data (Bradburn, 1969). For example, while all respondents with the exception of one expressed feelings of fear, insecurity and depression when asked informally about their self-concept, eleven of the fifteen rated their current feelings about self as very good (coded as 7) or good (coded as 6). Although in general there was consistency between the qualitative and quantitative information for each respondent there were some specific inconsistencies. When such inconsistencies appeared, I chose to accept the lengthier, more detailed information in the non-standardized part of the interview as I developed my model. Nevertheless, when inconsistencies did appear, I was forced to assess the findings more carefully. This worked as a check and balance system which substantially aided me in my analysis of the data. Combining two or more methodologies is recommended for future studies of this exploratory type.

\section{INTERVIEW GUIDE}

Guide For Non-Standardized Discussion of Responses of others

I would like you to tell me something about how people have responded to you and your situation since you've been separated.

How have they treated you?

Have they been supportive? In what ways?

Do they blame someone or something for the separation?

Do they think your separation was justified?

Are they committed to the institution of marriage?

Do they treat you differently now that you're separated?

(Inquire about relationships with: own relatives, in-1aw relatives, husband, children, close friends, friends you have as a couple, dates, new friends, acquaintances through work, community, etc.) 
At this point in the interview the standardized questionnaire on responses of others will be given to the respondents in written form.

\section{Guide for Non-Standardized Discussion of Self-Concept}

How would you answer the question, "Who am I"?

How would you describe your feelings with adjectives such as sad, happy, confident, lonely, independent, guilty, anxious, etc.?

Do you feel that you have something to offer the world? What?

Do you feel different now than you did when you were living with your husband? In what ways?

Do you feel comfortable in social situations?

What are you doing now that you enjoy? Work, community services, recreation, etc.

How do you feel about your ow sexuality now?

Do you feel like you have an understanding of what brought about the breakdown of your marriage? What?

Do you feel someone was at fault, to blame? Who?

Who asked for the separation?

What do you think your separation will lead to?

What do you want your separation to lead to?

Do you feel that your separation was a good thing, bad thing, necessary, not necessary?

How do you feel about marriage in general?

Do you think you might want to remarry if your separation ends in divorce?

What alternatives to marriage might be acceptable to you?

Did you (or you and your husband) seek any professional help prior to or during separation, e.g., psychiatrists, counselors, group therapy?

Have you used any such professional services at any other time in your 1ife? What? For what purpose?

How are you feeling, now compared to 1) prior to separation; 2) during the actual physical separation?

At this point in the interview the standardized questionnaire on selfconcept will be given to the respondents in written form. 


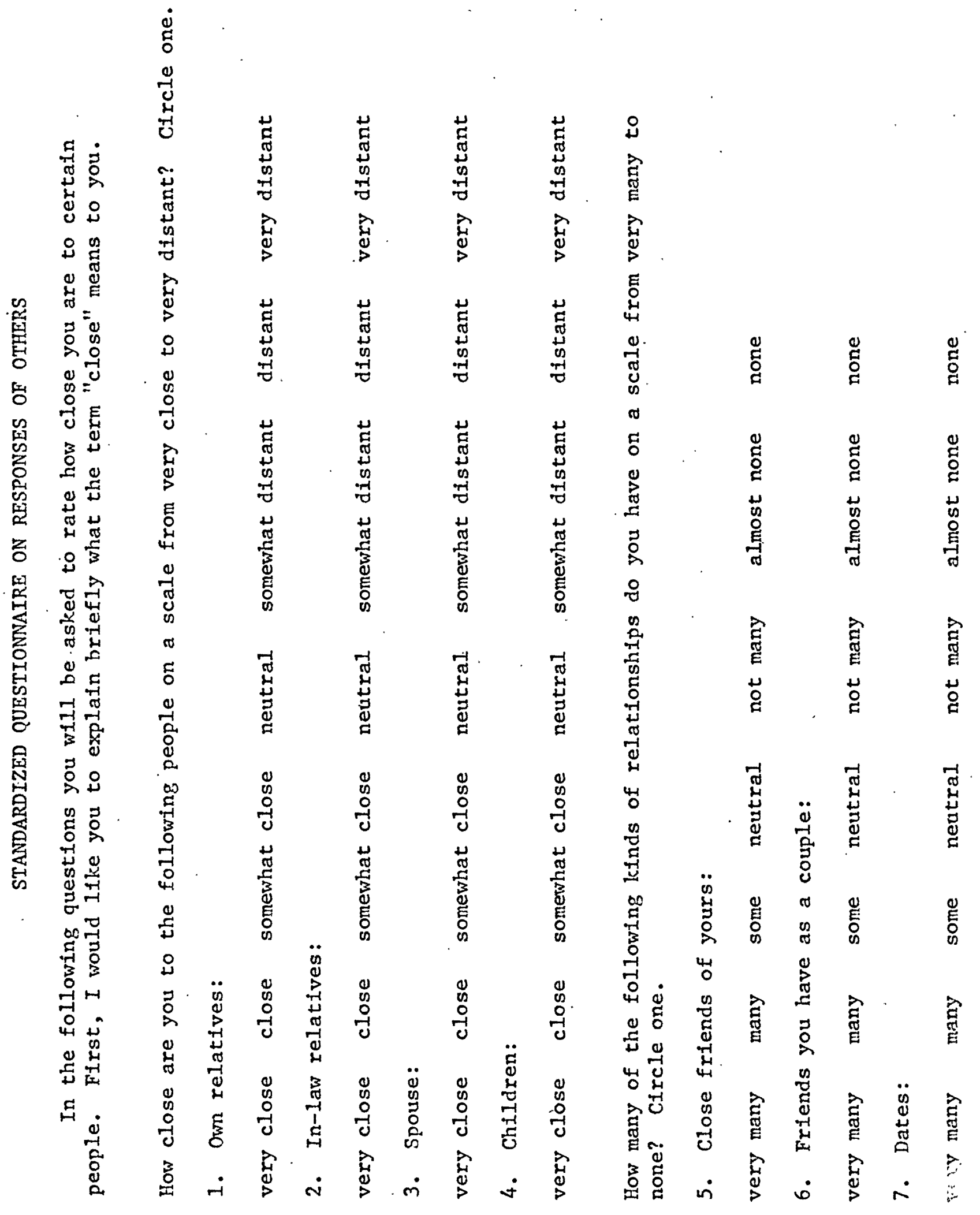




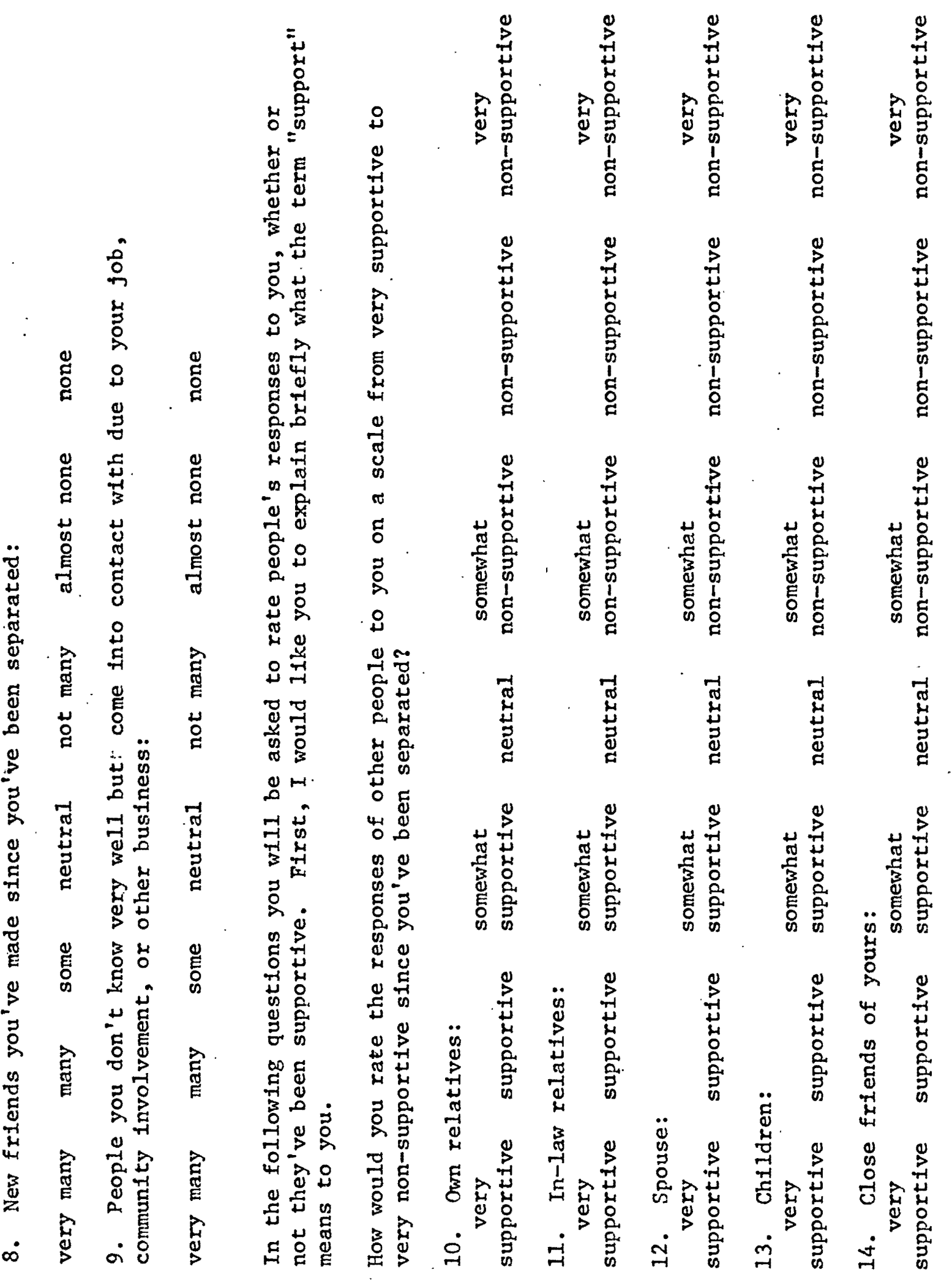




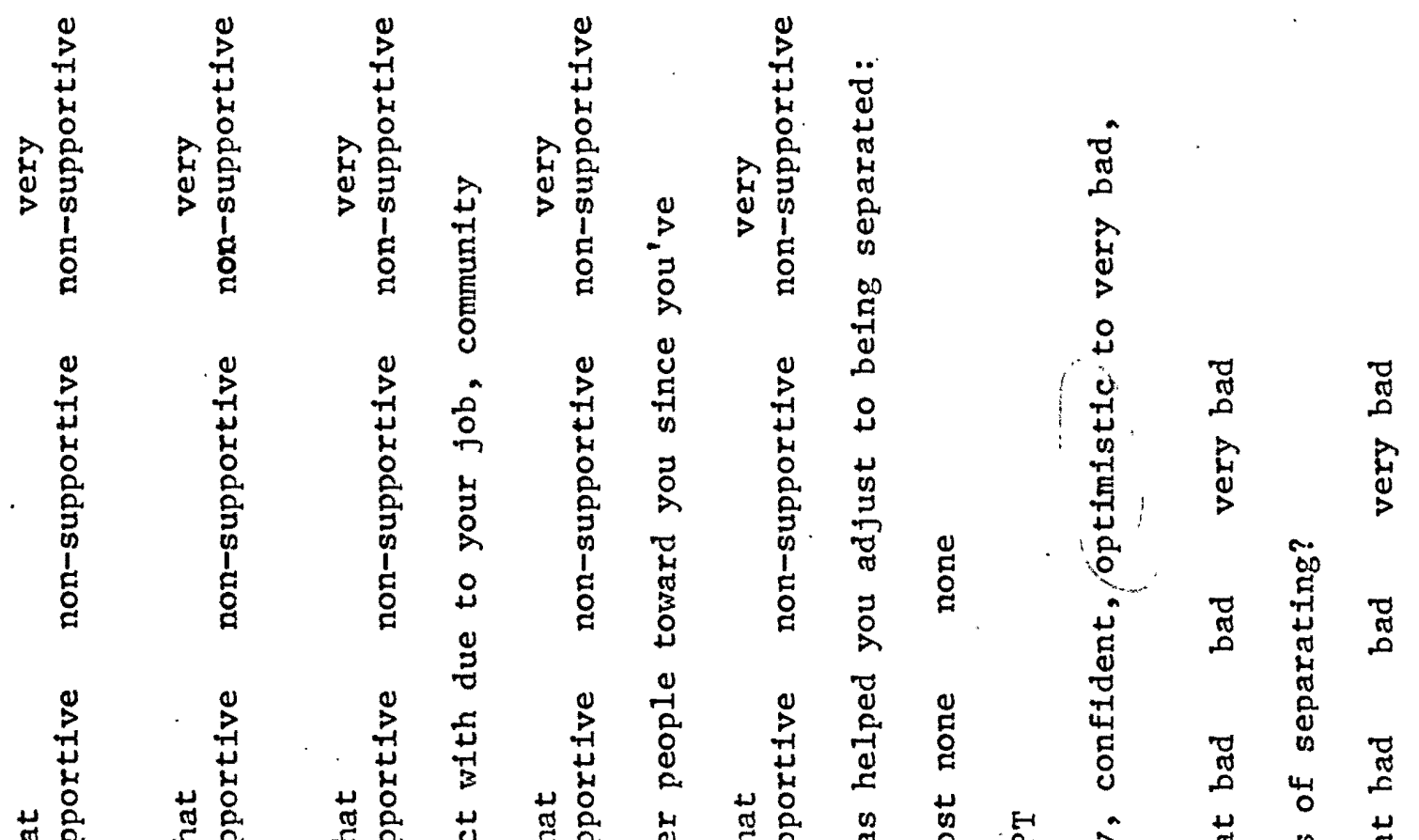

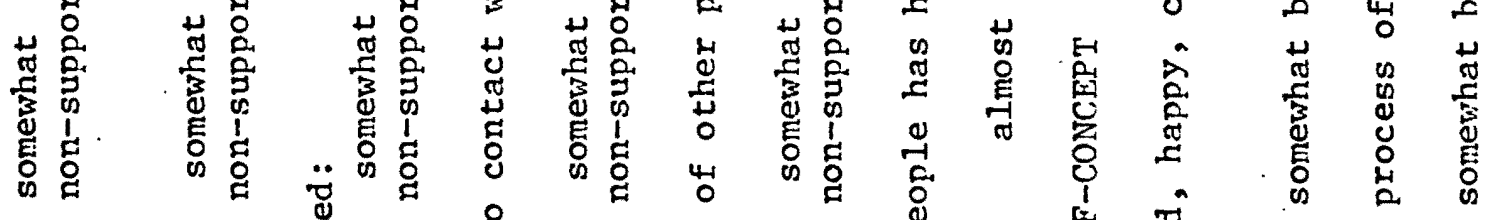

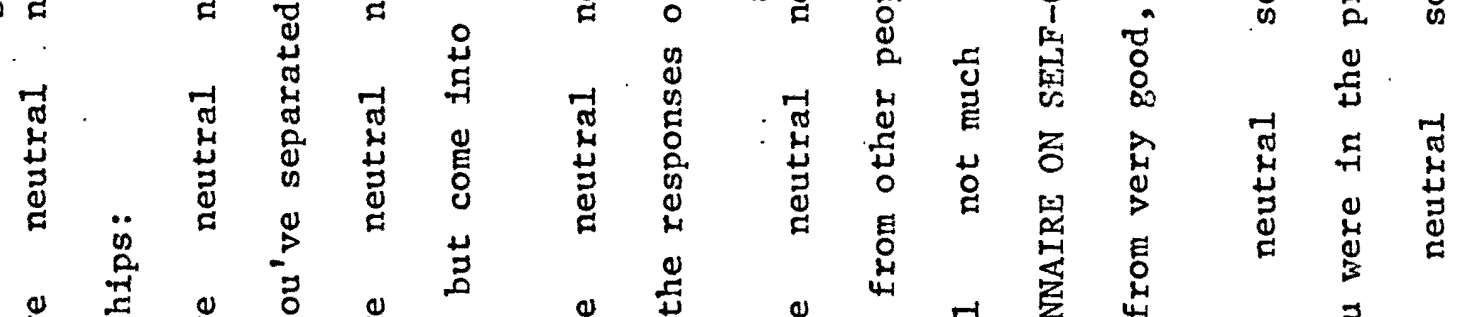

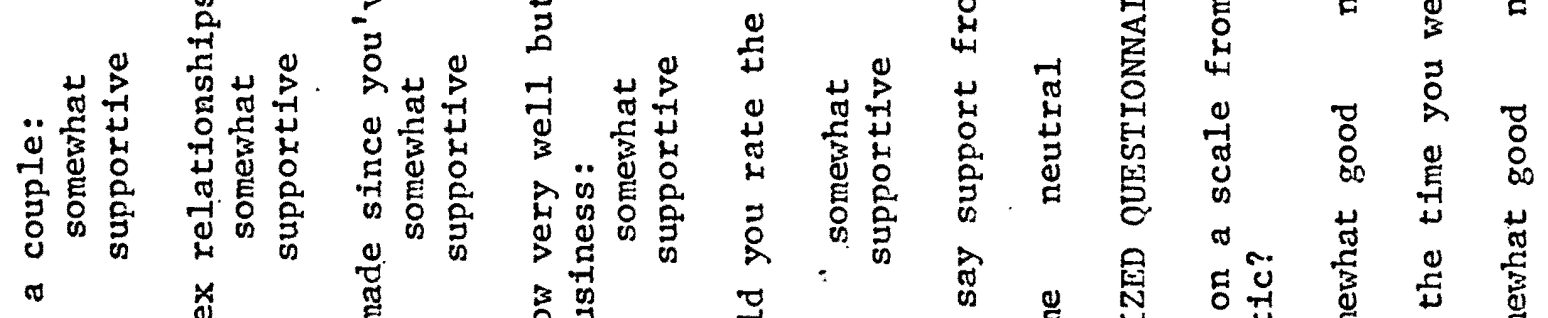

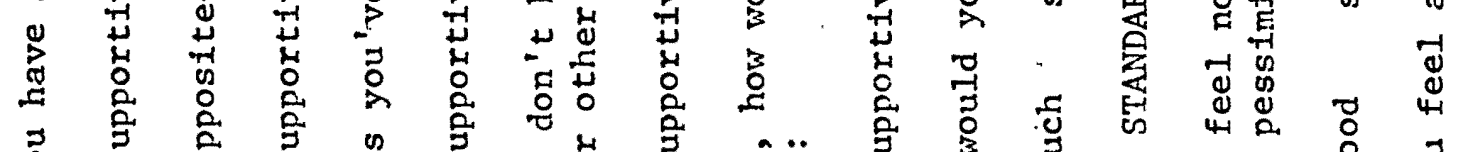

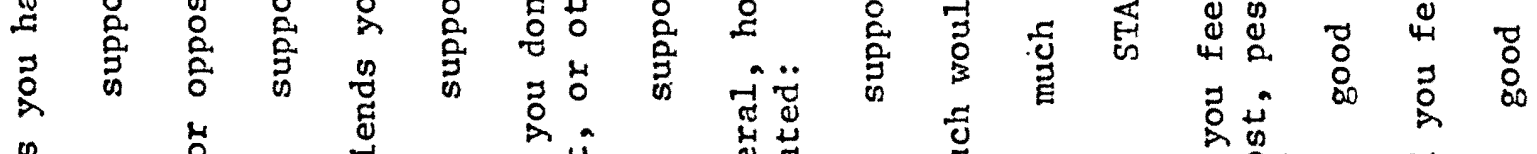

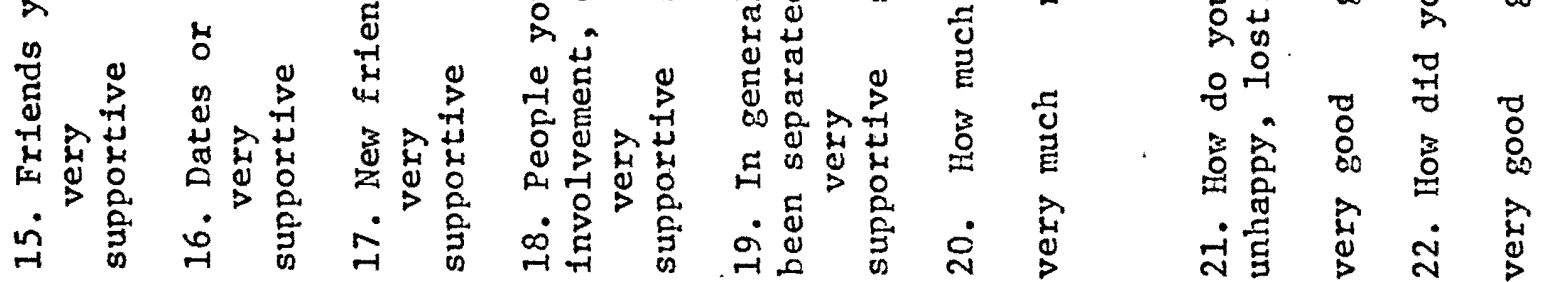




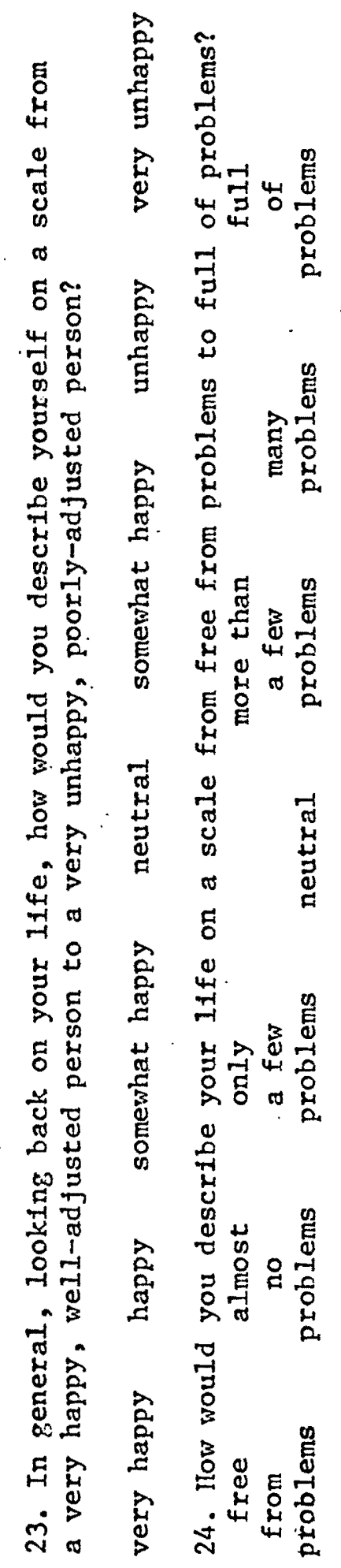


26

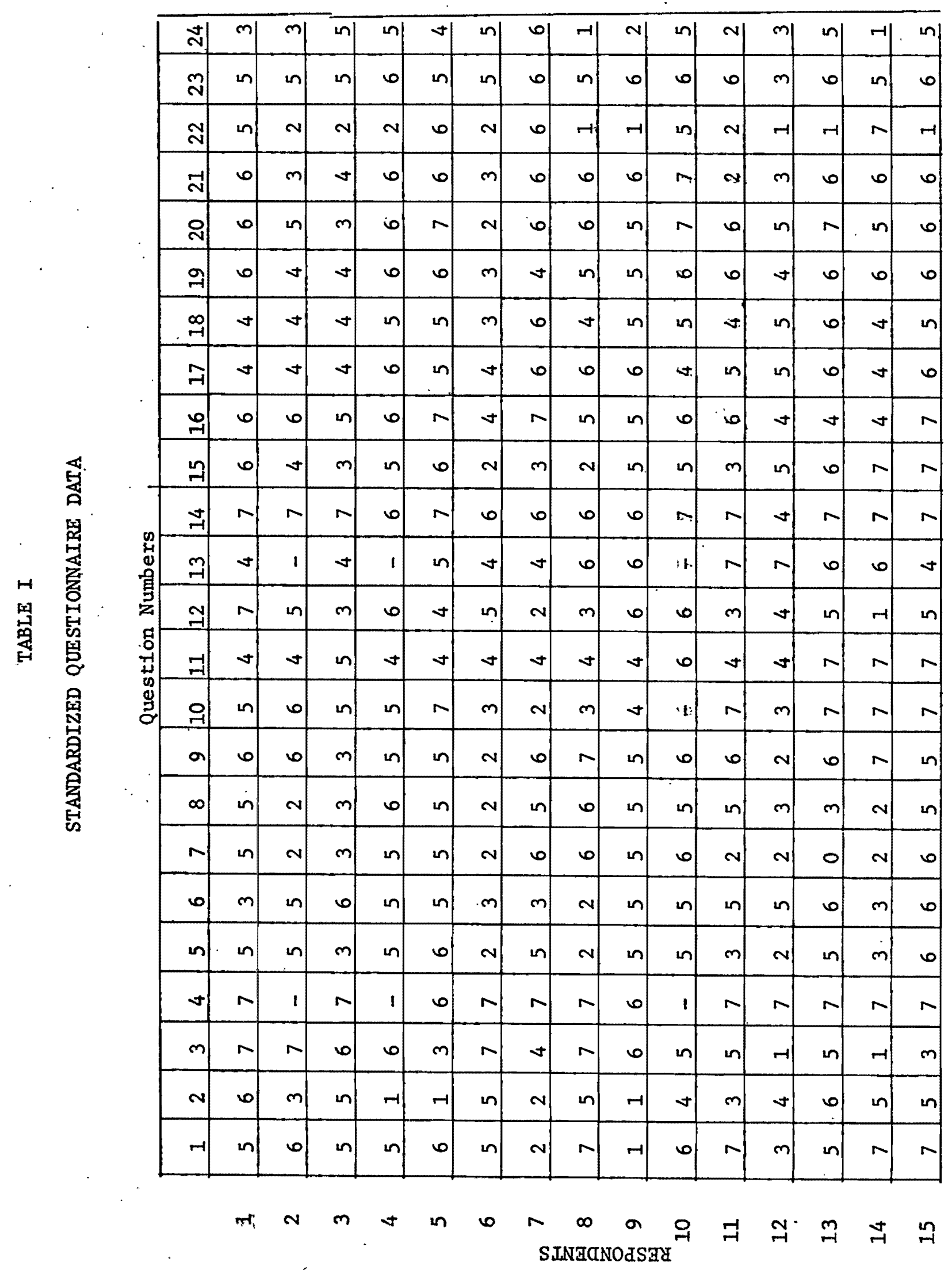


Characteristics of Individual Respondents

In the following chapters individual respondents w111 be referred to and quoted by a number, e.g., 非, 非, etc. These numbers were assigned on the basis of the order in which respondents were interviewed (非 was the first woman interviewed; 非15 was the last woman interviewed).

Following is a list of the characteristics of each respondent by number.

\#1 28 years o1d; married six years; separated one year; graduate student; two children.

\#2 28 years old; married six years; separated three months; graduate student; employed full-time as psychological counselor; no children.

\#3 32 years old; married ten years; separated five months; graduate student; employed part-time as office workers; three children.

\#4 26 years old; married five years; separated four months; graduate student; employed part-time in graduate studies; no children.

\#5 28 years old; married six years; separated two months; graduate student; employed part-time in graduate studies; two children.

\#6 34 years old; married 13 years; separated six months; graduate student; employed part-time as social worker; two children.

\#7 29 years old; married eight years; separated nine months (second separation; college graduate; employed full-time at social work agency; one child.

\$8 30 years old; married six years; separated nine months (second separation); college graduate; employed full-time at soclal work agency; one child.

H9 32 years old; married nine years; separated four months; college graduate; employed full-time at social work agency; two children.

\$10 30 years old; married seven years; separated five months; parttime undergraduate student; no children.

\#11 32 years old; married 12 years; separated six months; completed one year of college; six children. 
\#12 27 years old; married ten years; separated four months; completed $1+$ years of college; six children.

\#13 33 years old; married twelve years; separated seven months; college graduate; employed part-time in public schools; two children.

\#14 28 years old; married six years; separated ten months (second separation); part-time undergraduate student; employed full-time as secretary; one child.

\#15 31 years old; married eight years; separated two months; college graduate; employed full-time as secretary; two children. 


\section{CHAPTER IV}

\section{THE POSITIVE RELATIONSHIP BETWEEN SELF-CONCEPT}

AND RESPONSES OF OTHERS

In all fifteen cases, there was a positive relationship between self-concept and responses of others. Self-concept was assessed by asking respondents how they were feeling on a social-psychological level. They were asked to describe these feelings in terms of adjectives (lonely, sad, optimistic, independent, etc.); they were also asked to describe their contentment or discontent with various social roles (mother, single woman, employee, head of household, community worker, etc.). Responses of others were assessed by asking respondents how others in their social network were acting toward them since they had separated. They were asked about the amount and kind of support or non-support they had received from specific persons in their social network. These included relatives, close friends, couple friends, husband, children, dates, new friends, and people with whom they came into contact through work, the community, or other business. In addition to questions about these people, respondents described their perceptions of the responses of "others in general". The following cases 1llustrate how a posttive self-concept is related to positive views of the responses of others and how a negative self-concept is related to negative views of the responses of others. 
others was clear. The respondent said she was feeling very good and that she was very happy as a separated woman. She had gotten positive responses from all persons in her social network. Although she though that aunts and uncles were a little disappointed, she belleved that they would approve if they knew more about the situation.

I really do feel good about it all. And I do feel more independent. . . I've been happy ever since I left him for one thing; I just sort of smile all the time, and I really ifeel good.

My parents were ecstatic about it.

My closest friends thought it was wonderful.

We're (she and husband) good friends with each other, and he would help me if I needed him for anything.

I've just had a great social life so far. I've really been surprised at how much people cared, about like, is there anything I can do, or anything like that. They were really neat about it.

NUMBER 13

The positive relationship between self-concept and responses of others was also shown here: Although the respondent had felt bad at the time of separation, she was feeling good about herself now. She liked the feeling of being independent and thought that she had something to offer as far as skills and abilities were concerned. She had received positive support from all people in her social network. She had had no dates, however, and expressed a desire to meet men.

I lost a lot of sleep at first. But now, I don't know, I feel good about myself . . Yes, I like the independence.

(Something to offer) Sure; yes. My problem is I don't have a focus right now because I've done so many little things, so many short-term things in the last ten years . . But, sure.

(Relatives) First was shock, and then they gave me total support. 
They didn't turn me away.. . They placed no blame on me.. They were great.

(Close friends) Great. I have one friend in particular who has been, you know, she's been the one who's kept me from murdering anyone.

(Couple friends) They're great. (Still see them?)

Yes; sure. No one has ever taken sides with either one of us. If antying, they've taken sides on my part.

People have just been neat, much better than I expected.

NUMBER 8

The information given by this respondent also supported the view that there was a positive relation between self-concept and the responses of others. The woman said she was feeling independent and determined to prove that she could make it on her own. She felt very good about her own sexuality and her role as a mother. She was also gaining confidence in her job skills. She had received positive support from most people most of the time. She said that she had been included in social activities. She had also found it helpful to discuss problems with others, to find that she was not alone in having to face difficult situations.

I feel very independent for the first time in ages because I realize that I have to be; there is no one else that is going to make these decisions.

I'm a much better mother; we have a far better relationship now, and I think he and his father will have too.

(Own sexuality) I think it's the best thing that's happened. I'm not about to advocate being promiscuous; I'm not at all. But I'm able to relax and just enjoy my own sexuality for the first time in my life.

Some people that I just hardly knew, or that I thought were casual friends really pulled through; they've just been terrific. They would see that I was occupied; they would call and say I have someone I want you to meet.

(Dates supportive?) It really has because I was very fortunate in meeting someone that was an acceptable escort, 
someone I really enfoy being with.

(Hork supportive?) Yes, because you get out and you meet so many people with similar, almost identical situations. And it was very interesting to me to hear how they coped. If you're isolated, you tend to think that you're the only person in the world with these kinds of problems. It just helps to get out and talk to other people. .

NUMBER 2

This respondent's feelings were not all positive. She was feeling somewhat ambivalent about herself, in her words "sometimes good and sometimes bad". She was very lonely and anxious about what was going to happen to her in the future. She believed that as a single person she couldn't initiate social engagements with her couple friends. She was not sure what people thought of her now, but she had some fears that men might react to her negatively as a divorced woman. She hadn't dated much, nor had she met any new people since separating.

I definitely am lonely a great deal of the time. At night, and on the weekends, I'm very lonely, and I get very sad. I feel like I can't call up other couples. . . I feel like I'm kind of lost right now. I don't know what's going to happen to me in the future.

I feel like $I^{\prime} \mathrm{m}$ capable of earning a living. If $I$ didn't have that feeling, I would be very, very frightened. Sometimes I feel good about myself, and sometimes I don't.

Sometimes, if I'm home alone at night, and I get very lonely, I might have one drink, and then that goes to two and three and four, and I have a picture of me just sitting home alone at night every night of my life and kind of wasting away in the process. But in the daytime I feel, in some ways, more optimistic than I have in ages, feeling like, well, now that I'm not responsible to another person $I$ can really start to develop some things that heretofore have been undeveloped.

(What do friends think?) I'm not altogether sure. People whom I had known in the past, I guess are supportive, or feel that this is a crummy marriage and that I should be out of it. 
And I get very defensive when they say that. It's okay for me to talk about it, but I don't want them to say that to me.

I have a fear that men I meet in the future are going to think something like bad of me in some way for being divorced - not in a moral sense, but in a sense that It's sort of a tainted thing to be divorced.

I haven't really gone into what you would call the dating scene at all.

\section{NUMBER 6}

This respondent also reported feelings of ambivalence about herself. Although she had some confidence in her skills and abilities, she was feeling confused, lonely and scared. She felt that couple friends had turned against her, and she had not made many new friends. She would like some male companionship but didn't know where to find it. Her parents were very upset about the separation, and she said that she had to support them. There thus appeared to be a positive relation between self-concept and responses of others, both of which she perceived of as predominantly negative.

I feel really confused and alone right now. I think I really need to meet people. I do feel guilty that my family has been broken up, and I often get very upset about it. I just have no sense of where I'm going, what I'm going to do...

I feel I'm smart enough to do a lot of things, but I've just never had the experience. I do feel like. I'm nice-looking and a pretty good conversationalist . .

Friends we had as a couple have really dropped me. (Husband). still sees them alot . . . I think they blame me because they think I've adopted some new womens' lib, radical type of philosophy. . . It hurts me that these people, especially the women, were so quick to turn against me, because really these were the people who had been our friends.for years.

I really have almost no dates. Many times I'm just dying for a 
date, for male companionship at least, and I don't know how to go about finding it.

NUMBER 12

In this case the respondent had a negative self-concept and

felt that she had gotten no support from others in her social network. Althought she said she hoped to develop a better self-image, at present she lacked confidence in herself and felt lonely and scared. She felt as though her friends no longer had much interest in her, and she was not expecting much support from anyone. She hadn't had dates, nor had she met many new people since separating.

- . I doubt myself and think, you're just like you always were. I was dull; I was a real bore. And I was very dependent. And $I$ felt that $I$ was dumb.

I feel lonely and scared. I'm not lonely all of the time, but I'm scared most of the time. I think if I could get over being scared, then I'd quit thinking. that I want him back. . .

I thought everything was going to be terrific when I got back here because everybody was so concerned, but after about the first month, nobody seemed concerned any more. I don't expect much support from them (friends) any more...

One of my girlfriends criticized me a lot at first, but I didn't talke it personally because I knew that what she was saying was true. Then after a while I felt that she was just enjoying criticizing me.

I did meet one guy, and he came over and we talked a lot, and I was really starting to like him. . And then the guy who introduced us came over one day . . . and said, "He's married." And apparently my friend told him that he told me, and I haven't heard from him since.

An Ideal relationship between self-concept and response of others would be the following: strong, consistent, positive self-concept/ strong, consistent, positive responses of others; strong, consistent, 
negative self-concept/strong, consistent, negative responses of others. The data, as illustrated in the preceding examples, did suggest that women who had positive self-concepts also saw others as being supportive of them since separation. In contrast, women who expressed predominantly negative feelings about the self perceived support as being absent or as being critical or rejecting. The relationship was illustrated most vividly in the extreme cases $(\mathrm{e} . \mathrm{g} .$, \#10 in which self-concept was extremely positive and responses of all in the social network were seen as extremely positive). However, the majority of cases in the respondent group were not ideal types, i.e., self-concepts were not consistently positive or negative, and responses of others were not perceived as being consistently positive or negative. In addition, upon examination of the data a number of other factors were found to influence the self-concept/responses of others relationship. Thus, the development of a model in which categories were set forth to describe the properties of different types of self-concept/responses of others relationships appeared to me to be a useful analytical tool. In the following chapter such a model is set forth. 


\section{CHAPTER V}

THE MODEL

In this chapter a model is presented in the form of conceptual types which were built from the data. The data were in turn used to illustrate the types. Although categories did emerge which pointed to a variety of types of relationships between self-concept and responses of others during separation, it should be pointed out that the categorybullding process was often problematic. The decision to place a case in one type or another was often difficult as sometimes a case seemed to fit in more than one type or had some characteristic which did not fit with the others in that type. There were several different ways in which categorles could be organized and illustrated by focusing on concepts other than the relationship between self-concept and responses of others. For example, the data showed that there were a number of factors which impinged on the relationship between self-concept and responses of others. These factors included: 1). who initiated the separation; 2) the presence or absence of an understanding of what led to the marital dissolution; 3) whether the separation was defined as temporary or permanent and necessary or unnecessary by the respondent; 4) self-concept and situation prior to separation; 5) commitment to marriage. These factors were incorporated into the model by viewing them as properties of the different types of relationships between self-concept and responses of others. 
RESPONSES OF OTHERS : SUPPORT

Since responses of others were examined in terms of perceived support given respondents by others in their social network, it was important to examine the concept of support. Although respondents did not distinguish different kinds of support explicitly, I was able to discern two types of positive support. These I have labeled: 1) sympathetic support and 2) organizing support. These two types of support focused on the individual's self and situation in different ways. Sympathetic support was oriented toward the past; others responded to the separated woman's negative situation, e.g., mistreatment by her husband, un-called for rejection by her husband. This kind of support came in the form of verbal expressions of sympathy and sorrow over the individual's plight in being a separated woman. Rather than giving positive support of the woman's self-worth, sympathetic support gave a negative assessment of the husband's behavior. Organizing support, on the other hand, was oriented toward the present and the future; others responded to the separated woman's situation as a fact rather than as a negative crisis. It focused on the woman's adaptation to marital dissolution rather than on the marital dissolution itself. Often this kind of support came in the form of inclusion of the separated woman in social activities. It also came in the form of verbal reinforcement of the woman as a worthwhile and desirable human being. Although at times sympathetic support was perceived as comforting by the respondents, in general, it was less positively related to a positive self-concept than was organizing support.

Another distinction to be made is that between lack of support and negative support, e.g., criticism, blame. Lack of support refers to 
perceptions of the individual of having been left out, forgotten or ignored by others. From the data in this study it appeared that lack of support was related to a negative self-concept. This finding conflicts with the findings of Goode on divorced women. In his words:

- . the most favorable situation for low trauma is one in which the major reference groups are viewed by the respondent as being relatively indifferent to the divorce (Goode, 1956: 198).

It could be, however, that indifference to the divorce (or the separation) is quite different from indifference to the divorcee (or the separated individual). Goode does not explain exactly what is meant by indifference to the divorce. It could mean only that others did not place blame or take sides. Such a response, however, would indicate to me neutrality rather than indifference. It could also be that the relationship between responses of others and self-concept (or in Goode's terms, emotional trauma) is different for divorce than for separation.

In the case of negative support the individual perceives the actions and attitudes of others toward her as being negative, e.g., they blame her; they take the side of the husband; they abandon her; they criticize her. The findings in this study indicated that negative support was positively related to negative self-concept. Goode's study supports this relationship:

- . the highest proportion of high trauma cases were found when these various groups actively disapprove of the divorce (Goode, 1956: 198).

Again, however, Goode is referring to disapproval of divorce rather than disapproval of divorcee. In the present study the way in which others were perceived as responding to the separated individual was found to be more closely related to the individual's self-concept than was the way 
in which others were perceived as responding to the separation per se. In many cases in this study the respondents received both positive and negative support from the same person or from different groups in their social network. This is labeled ambivalent support. Although the majority of women sometimes saw ambivalence in response of others, in general, the responses of others were perceived as predominantly supportive or predominantly non-supportive. Five kinds of support emerged from the data: 1) positive; 2) positive/ambivalent; 3) positive/lacking; 4) ambivalent/lacking; 5) lacking. No respondents reported predominantly negative support. There were four self-concepts: 1) high positive; 2) low positive; 3) low negative; 4) high negative. Although lack of self-concept is a semantic impossibility, even a neutral self-concept was not expressed by any women in the group.

By combining variations in support with variations in self-concepts, five types of relationships between self-concept and responses of others resulted.

TABLE II

A TYPOLOGY OF THE S-C:RO RELATIONSHIP

Type

New Iffers

Revisors

Adaptors

Endurers

Mourners
S-C

High positive

Low positive

Low positive

Low negative

High negative
RO

Positive support

Positive/ambivalent support

Positive/lacking support Ambivalent/lacking support Lacking support 
ADDITIONAL PROPERTIES OF THE S-C:RO TYPES

As the data were collected, a number of behaviors and attitudes were found to be associated with primarily one or two but not all of the types. The following factors have been added to the model as properties of the different types; 1) who initiated the separation; 2) the presence or absence of an understanding of what led to the marital dissoIution; 3) how the separation was defined (permanency, necessity, effect); 4) self-concept and situation prior to separation; 5). commitment to marriage.

Who Initiated The Separation

In Goode's study of divorce, he found that the lowest trauma pattern occurred when the wife reported that initially the decision to divorce was mutual. Trauma was higher when the wife reported that she first suggested divorce and highest when the wife reported that it was her husband who did so (Goode, 1956: 136).

At first it may seem as though the question of who initiated the separation would be easy to answer. On closer examination, however, it was found that the individual who first explicitly suggested separating was not necessarily the individual who first implicitly suggested separating. Goode suggests:

- . In our soclety the husband more frequently than the wife will engage in behavior whose function, if not intent, whose result, if not aim, is to force the other spouse to ask for the divorce first (Goode, 1956: 136).

Goode found that in over $60 \%$ of his cases the wife sald that she first suggested the divorce (Goode, 1956: 135). In this study I attempted to determine who was the implicit initiator as seen by the respondent. 
Further references to the initiator are to the perceived implicit rather than explicit initiator. In some cases, of course, the implicit and explicit initiator was the same person. In some cases, although one spouse was the explicit inftiator, the decision to separate was seen by the wife to be implicitly mutual. For example:

We11, I think my husband did [explicitly suggest divorce]. He said a number of times over the past year that it just looks like we can't live together . . . and then he started to want to take that back, but in the end it was a mutual kind of decision. \#2

He originally asked for the separation, said he no longer wanted to be married to me. I had thought about it for a long time, but I guess I was afraid. But as soon as he left, I felt surprisingly good, relieved. $\# 5$

In this study eight women saw themselves as being the initiator of the separation. Three women saw the separation as a mutual decision. Four women saw thelr husband as being the inftiator of the separation. An Understanding of What Led To The Marital Dissolution

Another property of the types was the presence or absence of an understanding of what led to the marital dissolution, i.e., the separation. This factor has two aspects: 1) whether or not the respondent felt that she understood what caused the marital dissolution; and 2) what she saw as causing the marital dissolution. There were two general categories of responses reported as leading to the separation: 1) growing apart; and 2) faults of the husband. None of the women mentioned faults of their own as being the primary cause of the marital dissolution. "Growing apart" is a somewhat vague term, but in this study it appeared to refer to a process in which the married couple gradually developed a psychological distance between one another which impaired interpersonal functioning. This may have been due to interpersonal problems, e.g., 
sexual problems, communication problems; or it may have been due to a combination of some of the above. In Goode's study, the only category which could be considered to be similar to "growing apart" was labeled "value conflicts". According to Goode, only $8 \%$ of the women in his study listed value conflicts as being the primary cause of the divorce; in this study, eight of the fifteen women 1isted growing apart as being the primary cause of the separation. Goode concluded that education played an important role:

It seems consistent with the patterns we have analyzed that women with more education are more likely to complain of Value Conflicts . . . husbands of upper occupational strata are more likely to have this charge made against them. . (Goode, 1956: 131)

\section{Definition of The Separation}

In line with Thomas' theory of the importance of the "definition of the situation" in analyzing social-psychological phenomena, how the separated women defined their separation was related to the types. Women were asked to describe their separations in three ways: 1) Do you see your separation as temporary or permanent? 2) Do you see you separation as being necessary under the circumstances? 3) Do you see the separation as being a good thing?

None of the women thought that their separation was definitely temporary, expecting that it would end in reconciliation rather than divorce. In those cases where the women safd that their separation was permanent (in contrast to not being sure), the divorce papers had been or were about to be filed. In the cases in which women were unsure as to whether the separation was temporary or permanent, divorce had been filed in two instances. In these two cases $I$ thought that the expression 
of uncertainty was because the women wanted to save their marriages.

\section{Self-Concept And Situation Prior To Separation}

During the interviewing, I became aware that respondents were comparing self-concept and situation at the time of the interview to self-concept and situation prior to and during the actual time of initial separation. In other words, respondents of ten reported that they were feeling much better now than they had prior to and/or during the initial period of separation. Since all respondents were interviewed between two and twelve months after the actual physical separation, at the time of the interview the most intense period of the crisis (Goode, 1956; Bohannan, 1970) appeared to be over. The womens' self-perceptions were probably influenced by the amount of improvement they saw in their emotional state between the present and the past. The inference was examined by looking at: 1) How the respondent felt at the time of initial separation and 2) whether the respondent was feeling better about self and situation now than prior to separation. For the majority of women, separation was indeed initially a time of crisis and trauma. Only four women reported that they felt good at the time of actual separation. The remaining eleven women all said that they felt very bad at the time of separation. I also thought that j.t would be useful to get some idea of how the women perceived their self-concept in general. Thus, the women were asked whether or not, when looking back at their lives, they considered themselves to be happy, well-adjusted people. No differences were found among the responses to this question. All but one ("k12) said that they were generally happy and well-adjusted individuals. Perhaps if more specific psychological questions had been asked, a more precise 
picture of general self-concepts could have been discerned. There is some evidence to indicate that people are unwilling to define themselves as unhappy, poorly-adjusted Individuals (Bradburn, 1969). On the other hand, the women in this study (white, middle and upper middle class, educated) may in fact have had positive self-concepts in comparison to other kinds of women.

\section{Commitment to Marriage}

The final factor examined was that of the separated woman's commitment to the institution of marriage in general. In order to get this information, women were asked if they: 1) liked being married; 2) were committed to maintaining a marriage once it had taken place; 3) wanted to remarry should their separation end in divorce. It appeared that in general the respondents did not have negative feelings about marriage. All the women were at least somewhat committed to maintaining a marriage once it had taken place. The majority of respondents liked being married. Six women felt certain that they would like to remarry should their separation end in divorce, while eight were unsure about remarrying.

\section{TYPES OF S-C:RO RELATIONSHIPS}

\section{Type: New Lifers}

S-C: High positive

RO: Positive support

Organizing support

Three cases (\#1, \#5, \#10) most closely fit this category.

S-C: Felt extremely good about self and separation. Enjoyed sense of independence, being responsible for own life. Happy with social iffe and optimistic about the future. Had professional and/or academic interest and involvement.

RO: Own close friends and couple friends: both groups had given organizing support. They had not placed blame or taken sides. Interaction with married friends continued to be satisfying. 
Dates: women had received organizing support from men whom they had dated since separating. Had found relationships with men to be satisfying and enjoyable.

New friends: women had made new friends who gave organizing support. Anticipated meeting more new people through work and social activities.

Husband: women had friendly relationships with husband. Some interaction continued, but each leading own life.

Who Initiated The Separation:

$$
\begin{aligned}
& \text { Respondent initiator \#1 } \\
& \text { Respondent initiator } \$ 10 \\
& \text { Mutual inftiator } \quad \text { \#5 }
\end{aligned}
$$

At the time of the interview, all three women, whether they initiated the separation or whether it was a mutual decision, believed their husbands supported the separation. Thus, while none of the New Lifers felt that they had been "left" by their husband, none felt pressure from their husband to get back together. Respondents felt that others had neither taken sides nor blamed anyone for the separation. Others were not seen as feeling sorry for the respondents, nor were they seen as believing respondents had been rejected by the husbands. Others perceived the decision to separate in these cases as being mutual, or at least eventually so.

An Understanding of 'What Led To the Separation:

Do you have an understanding?

$\begin{array}{lr}\text { Yes } & \# 1 \\ \text { Yes } & \# 5 \\ \text { Yes } & \# 10\end{array}$

What led to separation?

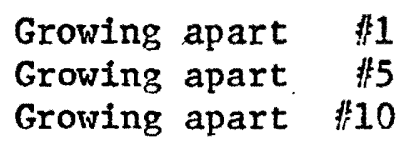

Al1 the New Lifers thought that they understood what led to the separation. One woman said: 
Yes; we've talked about it a lot, and we saw a marriage counselor; so we had it all pretty well-defined. 非10

Also, all New Lifers expressed feelings of having grown in different ways from their husbands. They didn't think that efther of them was to blame for the dissolution of their marriage; they simply believed that they were no longer fulfilling one another's needs. They saw their world views as being incompatible. For example:

I was no longer able to accept staying at home, providing a home for my husband to come to. I don't see being a wife and mother and having a career as incompatible. If I were willing to go back to being the kind of traditional wife my husband wants, I think I could probably save the marriage, but I don't want to at those costs. 非

No; no one was at fault. We're really different, and we got more different as we grew. \$10

Definition of The Situation:

1. Separation temporary or permanent?

Permanent 非

Permanent \#5

Permanent $\$ 10$

2. Separation necessary under circumstances?

Necessary 非

Necessary \#5

Necessary \#10

3. Separation a good thing?

$\begin{array}{lr}\text { Good } & \$ 1 \\ \text { Good } & \# 5 \\ \text { Good } & \$ 10\end{array}$

Al1 New Lifers thought that a divorce was certain (it had been filed for in two of the three cases), and that the separation and ensuing divorce were both necessary and good for them. 
Self-Concept And Situation Prior To Separation:

1. How feeling at time of actual separation?

Good \#1

Good : \#5

Good \#10

2. Feeling better now about self and situation than prior to separation?

\begin{tabular}{|c|}
\hline $\begin{array}{l}\text { Better } \\
\text { Better }\end{array}$ \\
\hline Better \\
\hline
\end{tabular}

New Lifers reported that they felt good at the time of the actual separation, indicating low emotional stress at the time during which the crisis of separation is thought to be most severe. New Lifers also reported that their feelings in general had improved since the marital separation. While no information was gathered on the length of time prior to separation during which marital problems were experienced, the phrase "prior to separation" may have been defined differently by different respondents.

Commitment to Marriage:

1. Liked being married?

$\begin{array}{lr}\text { No } & \$ 10 \\ \text { No } & \# 1 \\ \text { Ambivalent } & \text { \#5 }\end{array}$

2. Committed to maintaining a marriage?

Somewhat \#10

Somewhat \#1

Somewhat \#5

3. Remarry should separation end in divorce?

No $\quad \# 10$

Ambivalent \#1

Ambivalent $\$ 5$ 
The responses to the questions on commitment to marriage did not show consistent patterns of relationship within the five different types. However, New Lifers did have a relatively low commitment to marriage. The women either did not like or felt ambivalent about being married, were only somewhat committed to maintaining a marriage once it had taken place, and either did not want or felt ambivalent about remarriage.

\section{Type: Revisors}

\section{S-C: Low :Positive}

RO: Positive/ambivalent support Organizing and sympathetic support

Three cases (\#4, \#7, \#8) most closely fit this category.

S-C: Felt good about self and separation although at times felt lonely and sad. Were learnin?, more about self, enjoying feelings of self-growth and development. Were gaining confidence in professional skills and abilities.

RO: Own close friends and couple friends: both groups had given some sympathetic support but little or no organizing support. Some individuals in these groups had given negative support in the form of criticism or blame. Respondents reported that there were a few close old friends whom they considered important sources of support. Interaction with old married friends was noticeably less than prior to separation.

Dates: saw dates as being an important source of positive organizing support. Had positive interaction with men since separating.

New friends: had made many new friends since separating. Involvement in jobs and recreational activities had provided respondents with opportunities to meet new people. New friends perceived as important source of positive organizing support.

Husband: perceived their present relationship with their husband as ambivalent. Interaction characterized by erratic and unpredictable attitudes and behavior on the part of the husband. At times husband had given positive support, at times negative.

Who Initiated The Separation:

Respondent inftiator 
A11. Revisors saw themselves as the initiator of the separation. They all thought, however, that prior to separation their husbands had behaved in ways which the men likely knew could lead to separation. Thus, some behaviors by husbands might be seen as meaning a mutual initIation of the separation. None of the women thought that they had been "left" by their husband.

An Understanding of that Led To The Separation:

Do you have an understanding?

$\begin{array}{ll}\text { Yes } & \$ 4 \\ \text { Yes } & \$ 7 \\ \text { Yes } & \$ 8\end{array}$

What led to separation?

$\begin{array}{ll}\text { Faults of husband } & \$ 4 \\ \text { Faults of husband } & \# 7 \\ \text { Faults of husband } & \# 8\end{array}$

Revisors said that they understood what led to the separation. They all believed that their husbands' faults were primarily responsible for the dissolution of the marriage. The specific faults were described as follows:

I.think the main thing was [husband's] involvement in drugs. \#4 He's a very rigid person, and he's really hard to live with... He also had several affairs when we were married. \#1

He's very irresponsible in a lot of ways. He can't stand to come home at a certain time. And drinking was a real problem In his case; it was a pattern throughout our marriage. \#8

\section{Definition of The Situation:}

1. Separation temporary or permanent?

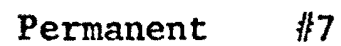

Permanent $\# 8$

Not sure \$4

2. Separation necessary under circumstances?

$\begin{array}{ll}\text { Necessary } & \$ 7 \\ \text { Necessary } & \# 8 \\ \text { Necessary } & \# 4\end{array}$


3. Separation a good thing?

$\begin{array}{ll}\text { Good } & \# 7 \\ \text { Good } & \# 8 \\ \text { Good } & \# 4\end{array}$

The Revisors, as the New Lifers, generally viewed the separation favorably, i.e., as being necessary and good. One woman was not sure that it was a permanent situation.

Self-Concept and Situation Prior To Separation:

1. How feeling at time of actual separation?

$\begin{array}{ll}\text { Bad } & \$ 14 \\ \text { Bad } & \# 7 \\ \text { Bad } & \text { \#8 }\end{array}$

2. Feeling better now about self and situation than prior to separation?

$\begin{array}{ll}\text { Better } & \text { \#4 } \\ \text { Better } & \text { 非 } \\ \text { Better } & \text { 非 }\end{array}$

Revisors reported that they were feeling bad at the time of separation. Also they reported feeling better at the time of the interview than they had prior to separation. Although these women reported that they were presently feeling good, these findings raised the question of whether the women were actually feeling good about their self and situation at the time of the interview, or whether they were just feeling better than they had prior to or during the actual separation. Further research would be required in order to answer this question.

Commitment To Marriage:

1. Liked being married?

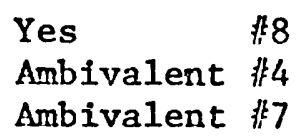


2. Committed to maintaining a marriage?

Somewhat \#8

Somewhat $\quad$ \#4

Somewhat $\quad$ \#7

3. Remarry should separation end in divorce?

Ambivalent \#8

Ambivalent $\quad$ \#4

Ambivalent $\quad \# 7$

From the data it appeared that Revisors had an ambivalent commitment to marriage, although there were less negative opinions than among the New Lifers.

Type: Adaptors

S-C: Low positive

RO: Positive/lacking support

Organizing and sympathetic support

Four cases ( $(\# 9, \ldots 13, \ldots 14, \ldots 15)$ most closely fit this category.

S-C: Felt good about self although at times feeling lonely and sad. Were learning more about self and were optimistic about the future. Thought that they had done all they could to make the marriage work. Had confidence in skills and abilities.

RO: Own close friends and couple friends: both groups had given both sympathetic and organizing support. old friends tended to believe the husband was primarily at fault. They had continued to include respondents in social activities. Respondents' own close frtends seen as important source of positive support.

Dates: had had only a few dates and expressed a desire for more meaningful relationships with men.

New friends: had only made a few new friends. People whom they had met since separating had been friendly but were not seen as an important source of positive support.

Husband: although some interaction with husband continued, it was primarily of a functional nature. Respondents reported that this relationship was presently characterized by an emotional distance. 
Who Initiated The Separation:

$\begin{array}{ll}\text { Informant initiator } & \$ 13 \\ \text { Mutual initiation } & \# 9 \\ \text { Husband initiator } & \$ 14 \\ \text { Husband initiator } & \$ 15\end{array}$

Adaptors saw their husbands as the initiators in two cases, themselves as initiator in one case, and the decision to separate as mutual in one case. The women who viewed their husbands as initiators of the separation also reported feelings of great anxiety and depression at the time of the initial separation. The woman who viewed herself as the initiator thought that her husband had engaged in behaviors which he knew would "force her" to separate.

An Understanding of What Led To The Separation:

Do you have an understanding?

$\begin{array}{lrlr}\text { Yes } & \# 9 & \text { Growing apart } & \# 9 \\ \text { Yes } & \# 14 & \text { Faults of husband } & \# 14 \\ \text { Yes } & \# 15 & \text { Growing apart } & \# 15 \\ \text { No } & \# 13 & \text { No understanding } & \# 13\end{array}$

Adaptors expressed some abiguity in their responses about the causes of the marital dissolution even though they said they understood what lead to the separation. For example, although one woman stated that her husband was at fault (he was running around with other women and he paid no attention to her), she said that she didn't understand why he was doing these things.

For a while I just sat around thinking, 'what did I do to deserve this? It was all my fault; I must have failed him, and that's why he was going out with everything he could get his hands on.' But then, my friends talked to me, saying, 'It's not your fault.' Now I feel like I was really stupid for thinking that. "非14

Another woman expressed a similar view:

I felt guilty for a long time, and then I couldn't find 
anything I was guilty of. No matter what I did wrong, I feel like I had the right to know what it was, and I don't know what it was. He just says !. that he's happier than he was before. \#13

Although the following quote is by a woman who felt that she understood what led to the separation, her responses hinted at uncertainty.

- .he's lots of fun to be with. Certain parts of us were very, very compatible, but emotionally I guess we were just not going to ever make it . . A marriage counselor told us that it looked like we were just not ready to make an emotional commitment to one another. \#9

Definition of The Situation:

1. Separation temporary or permanent?

$\begin{array}{lr}\text { Permanent } & \# 9 \\ \text { Permanent } & \$ 14 \\ \text { Permanent } & \# 13 \\ \text { Not Sure } & \$ 15\end{array}$

2. Separation necessary under circumstances?

Necessary $\quad$ \#9
Necessary $\quad$ \#14
Not Necessary $\quad$ \#13
Necessary $\quad$ \#15

3. Separation a good thing?

$\begin{array}{lr}\text { Good } & \# 9 \\ \text { Good } & \# 14 \\ \text { Ambivalent } & \# 13 \\ \text { Ambivalent } & \# 15\end{array}$

These responses showed greater variety among Adaptors than among New Lifers or Revisors. Here, although two women saw their separation as permanent, necessary and good, two women were somewhat ambivalent.

Self-Concept And Situation Prior To Separation: 
1. How feeling at time of actual separation?

$\begin{array}{lr}\text { Good } & \begin{array}{l}\text { \#14 } \\ \text { Bad }\end{array} \\ \text { Bad } & \# 13 \\ \text { Bad } & \# 15\end{array}$

2. Feeling better now about self and situation than prior to separation?

$\begin{array}{lr}\text { Better } & \# 14 \\ \text { Better } & \# 9 \\ \text { Better } & \# 13 \\ \text { Better } & \# 15\end{array}$

Adaptors generally felt bad at the time of separation and were feeling better at the time of the interview. As in the case of the Revisors, the interpretation of this must be cautious; specifically it cannot be concluded that the women now feel good, but only that they feel better than before.

Commitment to Marriage:

1. Liked being married?

$\begin{array}{lr}\text { Yes } & \# 9 \\ \text { Yes } & \# 13 \\ \text { Yes } & \# 14 \\ \text { Yes } & \# 15\end{array}$

2. Comnitted to maintaining a marriage?

Somewhat \#9

Yes \#13

Yes \#14

Yes : \#15

3. Remarry should separation end in divorce?

$\begin{array}{lr}\text { Yes } & \text { \#9 } \\ \text { Yes } & \# 13 \\ \text { Yes } & \$ 14 \\ \text { Yes } & \# 15\end{array}$

Compared to New Lifers and Revisors, Adaptors showed a high commitment to marriage. However, as noted earlier, Adaptors all thought: that they had done all they could to avold the separation. Thus, they 
reported that they did not feel guilty about the separation and did not feel that it was their fault.

Type: Endurers

S-C: Low negative

RO : Ambivalent/lacking support

Organizing and sympathetic support

Three cases (\#2, \#3, \#6) most closely fit this category.

S-C: Felt ambivalent about self--sometimes good, sometimes bad. Felt lonely, sad, depressed and frightened about future. Enjoyed some sense of independence, making decisions for self. Some confidence in professional and social skills.

RO: Own close friends: gave both organizing and sympathetic support. Own close friends considered an important source of positive support.

Couple friends: gave some negative support. Had little interaction with married friends since separating.

Dates: did not have many dates but expressed desire for meaningful interaction with men.

New friends: had not met many new people since separating. Although new friends had not given negative support, they were not seen as an important source of positive support. Although respondents had contact with others through work, school and/or other activities, these contacts had not been transformed into friendships.

Husband: relationships with husband still was very close and emotional. Frequent interaction characterized by positive support (in that they care about one another) and negative support (in that they can't commit themselves to one another as marital partners).

Who Initiated The Separation:

$\begin{array}{ll}\text { Informant initiator } & \$ 3 \\ \text { Informant inftiator } & \# 6 \\ \text { Mutual initiator } & \$ 2\end{array}$

Two Endurers saw themselves as inftiators of the separation, and one Endurer saw the decision to separate as being mutual. In all three cases the decision to separate was seen as making both husband and wife feel very sad and unhappy. In the two cases in which the women saw 
themselves as initiators, they also reported that couple friends saw them as the inftiators. They belleved that positive support was being given their husbands by couple friends, but was not being given to them (the respondents).

An Understanding of that Led To The Separation:

Do you have an understanding?

$\begin{array}{ll}\text { Somewhat } & \# 2 \\ \text { Somewhat } & \# 3 \\ \text { Somewhat } & \text { \#6 }\end{array}$

What led to separation?

Growing apart $\quad \# 2$

Growing apart 非 3

Growing apart \#

Although they thought that they only had a partial understanding of what led to the dissolution of their marriage, Endurers believed that the primary cause was groving apart. In contrast to New Lifers, however, Endurers thought that, in spite of growing apart, they were still very tied to their husbands. They appeared not to want to accept the irreversibility of growing apart.

It happened over a long period of time, and in some ways it seems like it should be reversible; it's impossible for me to ferret out every single cause of it. 非

My husband and I were very close in a lot of ways although our philosophies on life are very different. I guess they always have been . - We can't seem to break away from one another though, and I'm not exactly sure why ... 非

Definition of The Situation:

1. Separation temporary or permanent?

$\begin{array}{ll}\text { Not sure } & \$ 2 \\ \text { Not sure } & \$ 3 \\ \text { Not sure } & \$ 6\end{array}$

2. Separation necessary under the circumistances?

$\begin{array}{ll}\text { Necessary } & \text { \#2 } \\ \text { Necessary } & \text { \#3 } \\ \text { Necessary } & \# 6\end{array}$


3. Separation a good thing?

$\begin{array}{ll}\text { Ambivalent } & \# 2 \\ \text { Ambivalent } & \# 3 \\ \text { Ambivalent } & \# 6\end{array}$

None of the Endureres was able to clearly define her separation as being temporary or permanent. Although they did all believe that the separation was necessary under the circumstances, they were all ambivalent about whether the separation was a good thing. Endurers reported a great deal of uncertainty or ambivalence in their definitions of the separation.

Self-Concept And Situation Prior to Separation:

1. How feeling at time of actual separation?

$\begin{array}{ll}\text { Bad } & \# 2 \\ \text { Bad } & \# 3 \\ \text { Bad } & \# 6\end{array}$

2. Feeling better now about self and situation than prior to separation?

The same 非

The same 非

The same \#6

Endurers said that there was no improvement in their feelings about self or their situation. Their feelings were about the same as those prior to separation. The failure to perceive improvement may have been a part of their current predominantly negative self-concept.

Commitment To Marriage:

1. Liked being married?

Yes \#2
Ambivalent $\$ 3$
Ambivalent $\$ 6$.

2. Comitted to maintaining a marriage?

$\begin{array}{cc}\text { Yes } & \# 2 \\ \text { Yes } & \# 3 \\ \text { Yes } & \# 6\end{array}$


3. Remarry should separation end in divorce?

$\begin{array}{ll}\text { Yes } & \# 2 \\ \text { Ambivalent } & \# 3 \\ \text { Ambivalent } & \# 6\end{array}$

While the women were not consistently favorable about being married, all reported that they were committed to maintaining a marriage once it had taken place. Moreover, two of the three women were ambivalent about remarriage. In summary, Endurers were characterized by uncertainty and ambivalence.

Type: Mourners

S-C: High negative

Ro: Lacking support

Sympathetic support

Two cases ("k11, \#12) most closely fit this category.

S-C: Felt negative about self. Felt very lonely, sad and depressed. No confidence in job or social skills. Thought they had no Identity other than in the role of wife and mother. Had never expected.to find themselves in role of separated woman.

RO: Own close friends: gave some sympathetic support but little organizing support.

Couple friends: at first gave some sympathetic support but 1ittle organizing support. Respondents thought they had been dropped by married friends.

Dates: had almost no dates. Were pessimistic about possible future relationships with men. Felt there were few available men whom they would like and who would like them.

New friends: had not met many new people since separating. Had few activities which provided them with opportunities of meeting new people.

Husband: although respondents continued to have positive feelings for their husbands, such feelings were not returned. Thus, husbands seen as source of negative support.

Who Infitated The Separation:

Husband initiator \#11

Husband infitiator $\$ 12$ 
Both Mourners saw their husbands as the initiators of the separation, implicitly and explicitly. They reported that they had never wanted to separate and at the time of the interview were not in favor of the separation. They felt as though they had been rejected by their husbands. Friends and relatives also saw the husband as the initiator and blamed the husband for making the women sad and unhappy by having initiated the separation.

An Understanding of That Led To The Separation:

Do you have an understanding? $\begin{array}{ll}\text { No } & \# 11 \\ \text { No } & \text { \#12 }\end{array}$
What led to the separation?

$$
\begin{array}{ll}
\text { Don't know } & \# 11 \\
\text { Don't know } & \text { k12 }
\end{array}
$$

Mourners reported that they did not really understand why their marriages had terminated in separation. Their husbands had simply told them they "wanted out". They blamed their husbands in that they perceived them as not even willing to try to make the marriage work. These women did suggest some possibilities (e.g., maybe they were too dependent; maybe their husbands wanted to have a "fling"), but these statements seemed to be guesses rather than thoughtfully considered interpretations.

Definition of The Situation:

1. Separation temporary or permanent?

Not sure $\quad \$ 11$

Not sure $\quad$ \#12

2. Separation necessary under circumstances?

Not necessary \#11

Not necessary $\# 12$ 
3. Separation a good thing?

Bad \#11

Bad \#12

Although the husbands said that they wanted a divorce (divorce had been filed in the case of $\$ 12)$, these women said they were unsure if the separation would actually end in divorce. They were hopeful that it would not. They did not believe that their separations were necessary and said that, if their husbands were willing to try, the marriage would work. These two women were the only ones in the entire respondent group to state that their separations were a bad thing.

Self-Concept And Situation Prior To Separation:

1. How feeling at time of actual separation?

Bad 非11

Bad 非12

2. Feeling better now about self and situation than prior to separation? Worse \#11 Worse \#12

Mourners were feeling worse at the time of the interview than they had been prior to separation. They indicated that they had been happy when they were married and had been unhappy since separating.

Commitment To Marriages:

1. Liked being married?

Yes 非11

Yes $\$ 12$

2. Comnitted to maintaining a marriage?

Yes \#11

Yes $\$ 12$ 
3. Remarry should separation end in divorce?

Yes $\$ 11$

Ambivalent $\quad$ \#12

These women showed a high commitment to marriage. They liked being married and were committed to maintaining a marriage once it had taken place. One woman said that she definitely would like to get remarried if her separation did end in divorce. The other woman, whose husband had already filed for divorce, expressed some ambivalence about remarrying, saying she needed time to become more independent, to develop a more positive self-concept. She also felt embittered by her recent marital rejection.

DISCUSSION OF TYPES

\section{Self-Concept}

From the data, it appeared that there was a positive relationship between 1) self-concept and organizing support; 2) self-concept and amount of positive support; 3) self-concept and lack of negative support. The five types in the model differed in self-concept and responses of others both quantitatively and qualitatively. New Lifers had the most positive self-concept, and Mourners had the most negative self-concept. The differences in self-concepts of New Lifers, Revisors, and Adaptors were primarily quanitative. Endurers, however, differed qualitatively from New Lifers, Revisors, and Adaptors in that Endurers expressed a feeling of being lost, of not having any sense of future direction. Although Revisors and Adaptors expressed some feelings of anxiety about the future, they did not express this feeling of being completely lost. 
Mourners differed in self-concept from the other types in that the women felt consistently lonelier, sadder, more depressed, and more frightened. These women also differed from the women in the other types by being the only women who expressed an explicit lack of confidence in their professional and social skills.

Responses of others

Responses of others differed among the types in several different ways. New Lifers, Revisors, and Adaptors recelved organizing support from others in their social networks. Endurers and Mourners, on the other hand, received primarily sympathetic support. Although Revisors had received some negative support, they also had received no negative support (other than that from their husbands), they stressed their bitterness at the lack of support from others. They also lacked dates and new friends.

\section{Additional Properties}

The following properties were included in the model because 1) they had been previously. examined in studies on marriage and divorce, and, even more important, 2) they were consistently and repeatedly referred to by the women in this study.

1) Who Initiated the separation.

There also seemed to be some suggestion of a relationship between who initiated the separation and self-concept and responses of others. The differences were seen most sharply by contrasting New Lifers and Mourners. New Lifers saw themselves either as the initiator or saw the 
decision to separate as being mutual. They believed that, at the time of the interview, the separation was a mutual decision. Hourners, on the other hand, saw their husbands as the initiator of the separation. At the time of the interview they were still not in favor of the decisIon to separate. Although only one woman among the Revisors, Adaptors, and Endurers saw her husband as the initiator, the responses to the question of who initiated the separation were not expressed with the certainty that characterized the New Lifers.

2) An understanding of what led to the separation.

The data did show a relationship between an understanding of what led to the separation and the types. Women who understood what led to the separation appeared to be more likely than those who $\mathrm{didn}^{\prime} t$ to have a positive self-concept during separation. All but one of the New Lifers, Revisors and Adaptors (the one was an Adaptor) had an understanding of what led to the separation. All Endurers reported that they had only some understanding of what led to the separation, and both Mourners said that they had no understanding of what led to the separation. The majority of the women in the study ( 8 of the 15) reported that the primary reason for the marital dissolution was that they and their husbands had grown apart. All of the Revisors, however, attributed the marital dissolution as being due to faults of their husbands.

\section{3) Definition of the situation.}

Patterns of relationship were found between how the separation was seen and the types, again. most clearly in contrasting the two extreme types. A11 New Lifers defined their separations as permanent, 
necessary under.the circumstances, and a good thing. Both Mourners were uncertain whether the separation was temporary or permanent, believed that the separation was not necessary, and a bad thing. The definition of the separation was characterized by more ambivalence among Endurers than among. Revisors and Adaptors.

4) Self-Concept and situation prior to separation.

Women with the most positive self-concepts and responses of others experienced the least distress at the time of the separation. The majority of the women (11 of the 15) reported that they were feeling bad at the time of the initial separation. Three of the four women who said that they were feeling good at the time of the separation were New Lifers, and one was a Revisor. Improvement in self-concept seemed to vary by type. All New Lifers, Revisors, and Adaptors said that they were feeling better now than they had prior to separation, with the definition of prior to sparation left to the respondents. Endurers were feeling about the same as they had prior to separation, and Mourners were feeling worse than they had prior to:separation.

\section{5) Commitment to marriage.}

Some support, most evident in the extreme types, for a negative relationship between commitment to marriage and self-concept was found from the data. New Lifers either did not like or felt ambivalent about being married, were only somewhat committed to maintaining a marriage once it had taken place, and either did not want or felt ambivalent about remarriage. Mourners, in contrast, liked belng married, were comitted to maintaining a marriage once it had taken place, and either did want or felt ambivalent about remarriage. Adaptors and Endurers 
Also showed cansistent commitment to maintaining a marriage once it had taken place, whereas Revisors were only somewhat committed to maintaining a marriage once it had taken place.

\section{Relatives}

The data showed no patterns of relationship between responses of relatives and self-concept among the types. In most cases, the woman's own relatives were perceived as surprised and disappointed when initially told of the separation. After this initial response, the responses varied widely. Six respondents reported that their own relatives were very supportive. Four women reported that their own relatives were very supportive. One woman reported that she had received no support from her own relatives, and four women reported that they had received negative support from their own relatives. Of the six respondents who stated that their own relatives had been very supportive, two were New Lifers, three were Adaptors, and one was a Mourner. At the other extreme, of the three respondents who stated that they had received negative support from their own relatives, two were Revisors, one was an Endurer, and one was a Mourner. Most of the positive support given by own relatives was seen as sympathetic support.

In-law relatives were also seen as being disappointed that the separation had taken place. Generally, in-law relatives were not seen by the respondents as an important source of support, either positive or negative. On the standardized questionnaire, in-laws were rated as giving neutral support in ten cases. In two sases (one Revisor and one Adaptor), women said that they had received some negative support. 
(e.g., blame, criticism) from their in-laws. In these two cases rationalizations were given by the women for such negative responses. They did not appear to take these responses "personally".

The only person who has really reacted negatively is his mother, who's had a terrible history of mental illness . . . She's down and depressed all the time. I continue to stay away from hex. $\# 9$

She [his mother] tends to think that he's perfect, and since I'm the one who filed, that it's all my fault. He hasn't bothered to explain any of the reasons to her. He won't talk about it to her, so she doesn't know. And I don't feel like I should because it doesn't put him in the best 11ght; so $I$ 've just withdrawn from the relationship. \#7

In both cases, the women chose to withdraw from the relationship with those who gave negative responses. This was also true in the case of negative responses from own relatives.

My parents think it's a terrible disaster; mainly they just have a catastrophic kind of response to it; so I sort of stay away from them and don't tune in too much to what their responses are. Naturally I don't want that sort of input. 非

In cases in which respondents were close to their in-1aws and had positive relationships with them prior to separation, the same relationship continued after separation.

[Respondent very close to in-laws]. They've been just neat. I went back and spent three weeks with them this summer, and they're just neat. My mother-in-law particularly was afraid that she'd have no more contact with us, and when I wrote her and told her the situation, I explained that this didn't mean I'd changed my feelings toward her because I loved her very much. \#13

In cases in which the women were not close to their in-laws and had little Interaction prior to separation, such patterns also continued after separation. 
[Respondent not close to in-laws]. They live out of state; so they haven't been close enough to know what's going on. I think they were really shocked. I haven't talked to them. Our relationship has never been close; so I'm not too interested in getting their responses. \#5

Although respondents were asked about perceived responses of own relatives and in-law relatives, individuals in each category may have varied in responses to the respondents. The respondents usually first talked of parents and parents-in-1aw when asked about responses of relatives.

Responses of siblings and siblings-in-law were discussed by nine women. For five, a sibling was seen as an important source of positive support, and the sibling was seen more as a close friend than as a relative. For example, one woman said:

I've really depended on my sister. We talk all the time. I really consider her to be my best friend. \$3

No woman spoke of siblings as given negative wupport.

Relatives other than parents and siblings were mentioned by only three women, who reported that such relatives, e.g., aunts and uncles, did not really know much about the situation and responded neutrally. The data in this study, then, did not show patterns of relationships between responses of relatives and self-concept of the separated woman. Where the women percelved negative responses from relatives, they were able to explain such responses and/or avoid interaction. Also, positive support from relatives was viewed as of the sympathetic kind, which has been shown to be less closely related to positive selfconcept than organizing support. 
The meaning of the findings on relatives can only be speculative. The women considered their parents to be of a different generation and therefore to hold world views different from their own. Thus, their responses may not have been taken as seriously as those of their peers. Also, the women mentioned many times that it was natural for parents to be upset and disappointed when their daughter's marriage broke down, as if the respondents expected and accepted these reactions.

\section{Children}

Twelve of the fifteen respondents had children, ranging in age from two years to twelve years. Respondents had from one to six children. Although much has been written on the negative effects of separation and divorce on children, the women in this study did not see their separations as having strong negative effects on their children. Although the women expressed some feelings of guilt about their children, they also belleved that their children were actually better off since the separation, e.g., showing fewer signs of stress. For example:

At this point, it's almost like it's more peaceful for them. When [husband] was here, and we were fighting, [daughter] would cry. \#7

I'm a much better mother; we have a far better relationship now, and I think that he and his father will have too. \#8

The women all had custody of the children, and aithough fathers and children continued to see each other, the women said their children missed their father.

The women had difficulty in responding to questions about their children as sources of positive or negattive support. The women discussed 
the difficulties and problems involved in living alone with children, but they also expressed feelings of warmth and closeness with their children. Thus, although at times it was difficult to care for the children, at times it was conforting to have the children around. Most of the children had not directly expressed any feelings about their mothers' role in the marital separation. Perhaps this was due to their relatively young ages. The women did seer:some behavior changes since separation in their children, e.g., acting naughty, crying more often, but these were interpreted by the respondents as periodic and temporary. As one woman put it:

At times they act particularly naughty, and say something like, 'Then's daddy going to be here; he'1l let me do this.' And then I say to myself, 'Oh, no, this is because we're separated.' But then I stop and think that they used to say these same things before we were separated. $; 1$

In general, the women expressed optimism about their children's adjustment to the separation.

How Long Married

Data was collected from respondents as to the number of years they had been married before separating and to the number of months they had been separated. No relationship was found between type and number of months separated. However, the data did suggest a relationship between type and number of years married. The median number of years New Lifers and Revisors had been married was 6.3 ; for Adaptors the median was 8.8 years; for Fndurers the median was 9.7 years; for Mourners the median was 11 years. From these data it appeared that there was a negative relationship between self-concept and responses of others during separation and number of years married prior to separation. These findings could 
be interpreted to mean that adjustment to separation was most difficult for those women who had been married for the longest amount of time and easiest for those women who had been married for the shortest amount of time. Also, the two Mourners had married young (17 and 19), whereas New LIfers, Revisors, Adaptors and Endurers had all been married in their early twenties (between ages 21 and 24). Mourners did report that their identities had been totally tied up in the roles of wife and mother. 


\section{CHAPTER VI}

\section{IMPLICATIONS AND SUGGESTIONS FOR FURTHER RESEARCH}

As stated in Chapter I, the present study was exploratory, generating a model which could be useful for studies of the relationship between self-concept and responses of others. The number of interviewed women was small so that the researcher could examine in depth the relationship between their self-concepts and responses of others during marital separation. While the respondents were limited to women who were white, middle or upper-middle class, and between the ages of 25 and 35, I believe that the findings have meaningful implications for further research. Hopefully further research on the marital separation situation will be done which will support or modify the findings. Moreover, the findings are sufficiently broad to suggest their relevance to diverse populations (è.g., separation of a couple from their friends as they moved to another community; separation of children from home as they go off to college). In this chapter, implications of the findings for theory and further research are discussed. In addition, the limits of the model's applicability are examined. Finally, commonalities in perceptions of the women interviewed across types are discussed.

$$
\text { MODIFYING THE MODEL }
$$

\section{The Types}

According to Glaser and Strauss, in an exploratory study, the 
researcher continues to collect data until he/she finds that no new information is being found. As was pointed out earlier, however, the researcher can never be sure that saturation has taken place. A new category may emerge even after apparent saturation. In this study five types were identified which showed differences in the relationship between self-concept and responses of others during separation. Also, additional properties of these types were identified. I am aware that there may be other types as well as other ways of organizing types. Although these types and their properties have been shown empirically to exist, future studies might-indicate the existence of other types and/or a modification of the properties of the types set forth in this study.

Over Time Studies

One of the 1imitations of this study was the respondents were only Interviewed once, at some time between two and twelve months after the initial separation. Therefore, the only means by which changes in selfconcept and responses of others over a period of time could be assessed was by asking the women to reconstruct the past and anticipate the future. A more suitable way of examining changes over time would be to interview respondents at different times during the separation. Respondents admitted to having undergone many emotional changes from the time of initial separation to the time of the interview. Due to the one-shot nature of this study, I was only able to make tentative suggestions about the nature of the process of separation in regard to self-concept and responses of others. Although I identified categories of different types $S-C: R O$ of relationships during separation, it could be that these types represented certain stages in the process of being separated. Bohannan, for 
example, listed six stages of divorce. He called these: 1) the emotional divorce; 2) the economic divorce; 3), the co-parental divorce; 4) the community divorce; 5) the legal divorce; 6) the psychic divorce (Bohaman, 1970). Although he did not state that these six stages took place in a definite order, he did suggest that the emotional divorce usually came first and the psychic divorce usually came last. Although I found no evidence in this study which would support a theory of systematic stages regarding self-concept and responses of others during separation, It would be useful to examine the possible existence of such stages more closely. A study of the perceptions of separated individuals at different times in the separation process would facilitate such an examination.

\section{Perceptions of others}

In this study the perceptions of the separated women were examined In regard to the relationship between self-concept and responses of others. It would also be useful to examine the perceptions of significant others in the separated individual's social network regarding their responses to the individual and his/her separation. This latter approach was used by Glaser and Strauss in their study on death and dying. They collected data from inidividuals in the dying patient's social network in the hospital setting, as well as from the dying person. From this data they generated awareness of dying categories (Glaser and Strauss, 1965).

This study dealt only with perceptions of individuals as they were spoken and written for the benefit of the researcher. There is a1ways the possibility in this type of study that reactivity in the research process may influence the responses and therefore the results of the study. 
Due to the use of two techniques of data collection (written, standardized and conversational non-standardized)however, I believed that effects of the research process on responses could be more easily discerned. I also thought that informants in this study responded candidly and willingly.

\section{LIMITS OF THE MODEL'S APPLICABILITY}

\section{The Respondents}

The findings of this study must be limited to the respondent group as previously defined. Comparative studies on other separated populations would be useful in determining the limits of the model's applicability. For example, it would be useful to look at differences between 1) men and
women;
2) age groups;
3) social classes;
4) education;
5) income;

6) racial and ethnic group.

Another way in which differences, between groups might be examined would be to gather data on the relationship between self-concept and responses of others by contrasting separated people with people in other marital statuses (divorced, widowed, never-married).

\section{The Situation}

In this study people were interviewed who were in a specific crisis situation, i.e., separation. Therefore, the findings of this study may be specifically related to the separation situation. Further research might take advantage of the model to examine the relationship between self-concept and responses of others in other crisis situations. For example, the relationship between self-concept and responses of others might be examined during a time of financial crisis, after the death of a loved one, at the 
time of a severe illness, or after a criminal conviction. Generalizations about the model's applicability can be made only by doing comparative studies.

\section{COMMONALITIES}

Although the primary focus of this study was on differences in types of S-C:RO relationships, certain commonalities were indicated from the responses of the women. How far these comronalities can be generalized (to other populations, to a larger sample of the same population, to situations other than separation) can only be determined by further study. However, it seems useful to discuss these commonalities as they do suggest some areas for further research. Comnonalities to be discussed are labeled
as: 1) loneliness;
2) fear;
3) awareness of capabilities;
4) changing emotions
5) social isolation;

6) the desire for close, intimate opposite sex relationships.

\section{Loneliness}

Al1 but one woman ( 110$)$ reported that they had been lonely since separating from their husband. Even in cases in which self-concept and responses of others were positive, respondents stated that at times they felt very lonely due to the fact that their husband was no longer living with them. For example:

Sometimes that happens [feeling lonely]. Sometimes.I sit around and feel sorry for myself because there's no longer a warm body in bed with me. \#5

Oh, yes, absolutely bottomless pits of loneliness at times. \#14 
In cases in which self-concept and responses of others were positive, women were more likely to talk about loneliness without any special referent. However, in cases where self-concept and responses of others were predominantly negative, women were more likely to talk about loneliness in terms of their husband.

- . sometimes I miss him [husband] and feel so lonely that I think I'm more willing to make changes that would be necessary if we were to work anything out. \#6

I'm lonely and scared. I think I need him, and as soon as

I know that $I$ don't need him, then maybe $I$ '1l really know how

I feel. \#12

It appeared to me that many of the expressions of loneliness were due to the loss of a taken-for-granted other in their social environment. Says Bohannan:

People who have been long married tend to have become socially part of a couple or a family; they lose the habit of seeing themselves as individuals (Bohannan, 1970: 32).

Women in the study group had been married from five to twelve years prior to separation, and they had simply become accustomed to living with their husbands. Although many of them were still living with people, i.e., children, such people did not seem to compensate for the loss of the adult mate. Since only one of the respondents was living with another adult at the time of the interview, it would be difficult to assess to what degree feelings of loneliness might be lessened by having an adult companion (either male or female) in the household. In the one case (\#14), the respondent was living with her mother, with whom she had a very close relationship. Although she did report feeling lonely at times, she did see her mother as being an important source of positive support; she often referred to her mother during the course of the interview. 
Fear

Another feeling that was repeatedly expressed by the respondents was that of being afraid. Although the women expressed feelings of fear about being separated and on their own, what they were describing was more like anxiety. They were not afraid of being unsafe; nor were they afraid of any specific phenomenon. Rather they expressed a general concern about whether or not they could "make $1 t$ " on their own. At times it was unclear whether "making it on my own" referred to economically making it or emotionally making it. Then the women were questioned about this distinction, they were not sure which they meant. Both factors probably contributed to these anxious feelings. Feelings of fear (anxiety) are 1llustrated in the following statements:

Being on your own is very frightening, and I realize how much information I lack. \#8

I feel that I'm kind of lost right now. I don't know what's going to happen to me in the future. 非

I now realize the overwhelming task of taking charge of your own $11 \mathrm{fe}$. . . I guess I've always felt that at some time we'd get back together again, and now I'm feeling more unsure about that and really trying to face the fact that it may just not be possible. It really scares me. 非6

I'm learning to gain strength, learning more about myself, but I'm scared, and I'm lonely. \#9

All but one of the women saw themselves as being financially secure prior to separation because their husbands had average or above average steady incomes. Although all but one ( $\$ 10)$ experienced a loss of income after separation, most were earning income themselves and/or receiving adequate financlal support from their husbands. None could be classified as "financially desperate". All but two (both Mourners) expressed some 
degree of confidence in their own job:skills. The fear that they expressed about coping with the future appeared to be due in part to their having been accustomed to being supported by their husbands. Separation was accompanied by a sense of a loss of security which was expressed as fear. This suggests that the role of married women in our society (being dependent on and supported by the husband) leaves women ill-equipped to carry the responsibility for their own lives when their role as wife is terminated. An examination of this phenomenon in regard to separated men in our society would be useful.

\section{Awareness of Capabilities}

Although respondents expressed feelings of anxiety and fear during separation, they also expressed a sense of newly-recognized independence and accomplishment during separation. They found that they could do many things that they had not realized, prior to separation, they could do. They said that they had been dependent on their husbands, and that separation had forced them to give up this dependence. Most of them were pleased with this recognition that they were capable of functioning independently.

I love that notion of feeling independent because I've never been independent before in my life, fust never. I couldn't even hardly write a check. My husband did all of that, and so for the first time I truly am independent, and I really like that notion. \#9

Things that I used to depend upon my husband to do, even if It's a little thing like changing a light bulb that's way up on the ceiling or something. Something as simple as that can give me a feeling, a sense of real accomplishment, that I can be self-sufficient. So I feel more in charge of myself, more a master of my own world. 供 2

I feel very independent for the first time in ages, because I realize that I have to be; there is no one else who is going 
to make these decisions. \#8

I am enjoying some feeling of independence or autonomy, and while it's kind of scary to me, I do like the feeling that I'm responsible for myself. 非

I'm making my own decisions now, like even what I want to do during the day. I used to make lists of things that just totally controlled my life. So I'm making my own decisions, and I'm happy about that. $\$ 7$

These data also suggest that the role of wife in our society is a dependent one. Expressions of satisfaction and pleasure in being independent suggest, contrary to some earliex assumptions, that the nature of women is not such that they are only comfortable as dependent and passive beings.

\section{Changing Emotions}

Women in the respondent group reported that from the time of the Initial separation up to the time of the interview their emotional feelings had changed frequently. There did not appear to be any systematic pattern of emotional changes. In other words, feelings of sadness, fear, happiness, Ioneliness, confidence, depression, etc., came and went depending on the day or the week.

I've sort of gotten into a place where I feel like feelings come and go. And whenever I am in the past, I'll go on to something else. So I don't stay with any one feeling state for a long time; I don't get an over-all view of myself as lonely or guilty or whatever.

Sometimes I feel like if the next ten years are as shitty as the last ten years, then I might as well kill myself right now because it's not going to be worth 1 t. It just depends on my general outlook at the time. Two weeks ago I was on the greatest high I've ever had. I probably haven't been that high emotionally in eight or ten years. But then . . . all of a sudden you wonder what it's all about. \#14 
I'm beginning to feel good, but then you're catching me on a good day. There are bad days. \#12

In his'study on divorce Bohannan found that the working out of emotions was a complex task for the divorcee. He concluded:

When grief gets entangled with all the other emotions that are evoked in a divorce, the emotional working through becomes complicated ... (Bohannan, 1970: 37-38).

The women indicated that they had engaged in a great deal of selfreflection since separating and that such self-reflection was often characterized by ambiguity and uncertainty about who they were, what they wanted, where they were heading, etc. Separation appeared to be a time of change and transition which often lacked direction; thus, the separated Individual's feelings often went back and forth as she reflected on her situation. One woman said:

Sometimes I think maybe I would like to get divorced. Being separated is really ambiguous. Then you're separated, you're really nothing. \#4

Although it did appear that self-concept underwent many changes during separation, the data in this study did indicate that general selfconcepts (ranging from positive to negative) could be identified for different individuals during separation.

\section{Soctal Isolation}

Many women expressed the bellef that the single. woman was often excluded from social activities in which she would be included if she had a male partner. Respondents believed that this need for a partner in order to be included was more of a problem for single women than for single men. Married couples were seen as uncomfortable with single women in social activities. Therefore, the respondents often felt 
uncomfortable with married couples.

I feel like I can't call up other couples, that if I'm going to do something with somebody, it has to be a single person. \#2

I did go out one time with two couples, and I felt really dumb. \#15

- . I feel that there really is no place for a divorced woman in this vorld. People are threatened by a divorced woman, and there's no real place that a divorced woman fits into . . . I don't have a lot of single friends, and my married friends don't include me for some reason or another. 非

In addition to believing that the single woman often was not included in social activities with married couples, the respondents perceived the fact of their separation as being disturbing to their married friends in that it threatened the friends' reality. This was well-expressed in the following statement:

People [couple friends] were really shocked, and let down and disappointed, feeling fragmented, like here's another point of stability that's not there any more. I think that everyone wants to see this family ideal, and they look at you, and they hope that it's happening there with you. And then when that breaks apart, that breaks their myth, or takes a little part out of their myth. \#1

And similarly:

- $\because$. even though they [couple friends] had known that there was some tension and strife, they were very upset. They considered us to be a couple, and they seemed to want us to stay together. \#2

Thls threat was often given as an explanation of why couple friends

had lessened or discontinued interaction with the separated woman.

It scared a lot of them [couple friends], and I no longer have a lot of contact with them. I'd say the majority of them were basically afraid of the separation. They had set us up as the ideal couple, and I think they felt that if we vere to get a divorce, then it might rub off on them. $\$ 7$ 
I think that people want to pretend that things like that

-- that it's not happening; so they just sort of casually

drop you off their list or whatever. 非11

In his study on reactions of friends to divorce, Miller reported that friends could experience an emotional loss over the divorce of members of their friendship circle. Such a loss may arouse feelings of anxiety and fear in the married friend. Miller added that this may be due to the fact that he/she had found his/her own marriage less than satisfactory. Miller also referred to the fact that friends sometimes have idealized the marriage of others and that when a divorce occurs, this ideal is then shattered. He continued: "Friends sometimes respond to a divorce with complete surprise. Along with the surprise there is incredulity and the protest that 'it cannot be'." (Miller, 1970: 66) In order to avoid conflictual or unpleasant feelings, friends of divorcees may withdraw from interaction with the divorcee. According to Niller, "Such a phobic avoidance may be a protective posture ..." (Miller, 1970:72) Bohannan also noted that friends responded differently to the person who was divorcing because he/she ceased to be a part of a couple. Bohannan found that: "The biggest complaint is that divorcees are made to feel uncomfortable by their married friends." (Bohannan, 1970: 52) The perceptions of the women in this study in regard to responses of married friends, then, supported the findings of previous studies on people who were divorcing.

Desire For Close, Intimate Male/Female Relationships

Al1 but one respondent (代10) expressed some desire for eventually having a close, intimate relationship with a man. This desire was not 
necessarily expressed in terms of marriage; many of the women thought that they might live with someone without being married. Others thought that they would just like to "have someone" with shom they could intimately relate. The response of the women also suggested that exclusivity was desirable in a close, intimate male/female relationship.

I don't think anything. can beat how comfortable a good relationship is. You've got a strong sense of security; you're emotionally assured. You're self confident . . . I just think it's an emotional and mental state you can't beat. . . 非 14

I enjoyed being married. I hate to look forward to living the rest of my life alone... I know that there's no guarantee, but I don't want to get involved in one that I don't think has a chance of being permanent. $\|_{13}$

I'm really committed to eventually having a solid, intimate relationship with a man. I feel like that would bring me happiness. 非 3

I like being close and having someone . . . $\# 8$

I may be kind of holding out for another intimate $\because$ relationship. I guess I still do believe that there may be somebody with whom I can find constancy, security and still continuing excitement. 非

Although no one expressed the belief that living with someone outside of marriage was immoral, five of the twelve women with children expressed some concern about the effect living with someone outside of marriage might have on thetr children. For example:

- . living with someone without marriage presents certain problems for me because of my children. \#3

I think it (Iiving with someone outside of marriage) would be hard to deal with because of my children . . . 12

If I didn't have any children, I feel like I would [1ive with someone]. \#8

When questioned about specific effects they thought living with someone without being married might have on their children, the respondents were 
unable to give any definitive, precise answers. In most cases they simply reiterated that it would be generally problematic.

$\because$ The women in this study, then, did not appear to be "liberated" from a primary focus on a successful, intimate relationship with a man as a desirable goal. The women also indicated that they desired such a relationship be monogamous in nature. The extent to which this finding would be supported and could be generalized to other groups could only be determined by further research.

\section{Concluding Remarks}

It has been repeatedly suggested in symbolic interaction theory (ploneered by George Herbert Mead and Charles Horton Cooley) that one's self-concept is learned and reinforced through interaction with others. The responses of others in an individual's social network are said to be related to the way in which an individual views himself/herself. However, this relationship has recelved little empirical attention.

In this explanatory study the S-C:RO relationship was examined during a marital crisis, i.e., separation. Literature on marriage and divorce indicates that marital dissolution is a crisis situation during which perceptions of self are reflected upon and reorganized (Goode, 1956; Bohannan, 1970). Based upon this information, I decided that an examination of the S-C:RO relationship during separation would be highly pertinent to the question of whether or not a self-concept is related to percelved responses of others.

In order to examine the S-C:RO relationship during separation, data were collected in the form of in-depth interviews with fifteen 
white, middle class women between the ages of 26 and 34 . Given the limited sample, the results of this study cannot, of course, be generalized. A typological model was generated from the data showing different S-C:RO relationships. The model consisted of five types: 1) New Lifers (S-C: High positive; RO: positive support): 2) Revisors (S-C: low positive; RO: positive/ambivalent support): 3) Adaptors ( $S-C$ : positive/lacking support); 4) Endurers (S-C: low negative; RO: ambivalent/lacking support); 5) Mourners (S-C: high negative; RO: lacking support).

A positive relationship was found between self-concept and responses of others during separation. Thus, the findings did support interaction theories which emphasize a connection between the vay in which individuals feel about themselves and the way in which individuals perceive others as feeling about them. However, the data were not sufficient to make generalizations about cause and effect patterns in the relationship. For example, it could be that the women perceived others as responding positively to them (cause) and thus felt good about themselves (effect). On the other hand, it could be that women who were feeling good about themselves (cause) also perceived others as responding to them positively (effect). As the data were examined and the model developed, it was found that there were several factors aside from Ro which were related to the types in different ways. These factors were included in the model as properties of the types. Data showed that there was 1) a positive relationship between self-concept and respondent as initiator or mutual initiation of the separation (e.g., Mourners saw their husbands as initiators); 2) a positive relationship between self-concept and an understanding of what led to the separation; 3) a positive relationship between self-concept and perceiving 
the separation as permanent, necessary and good; 4) a positive relationship between self-concept at the time of the inter- iew and selfconcept at the time of initial separation; 5) a negative relationship between self-concept and commitment to marriage. These relationships were most strongly seen by contrasting the extreme types (New Lifers and Mourners).

Although the initial focus of the study was on differences between S-C:RO types, the data also indicated that there were certain commonalities which applied to all the types. Commonalities found and discussed were:
1) Ioneliness;
2) fear;
3) awareness of capabilities;
4) changing

emotions; 5) social isolation;

6) the desire for close, intimate opposite-sex relationships. Further research would be required in order to determine the extent to which these commonalities apply to separated people (or people in crisis situations) in general.

This typological model would appear to be a useful analytical tool for further research in several ways: 1) it provides a framework within which the S-C:RO relationship can be examined for different groups and different situations; 2) it sets forth a specific way in which different types of separated individuals can be identified and described; 3) it provides a framework within which the effects of separation on husband/wife can be examined. At present there is a dirth of empirical studies on the S-C:RO relationship and on separation. The findings of this study should be interpreted cautiously, as they are based on data gathered from a sma11 and 1imitied respondent group. However, the indepth interviews brought forth information about the nature of selfconcept and responses of others during separation which can be examined 
in future research. The typological model which resulted from the study can be conceptually and methodologically useful for such further research. 
BIBLIOGRAPHY

Berger, Peter L. and Hansfried Kellner

1970

"Marriage and the Construction of Reality, in

Dreitzel, Peter, ed., Recent Sociology, No. 2,

New York: The Macmillan Company.

Berger, Peter L. and Thomas Luckmann

1967

Bernard, Jessie

1970

Blumer, Herbert

1962

Bohannan, Paul, ed. 1970

Bolton, Charles D. 1961

Bott, Elizabeth 1957

Bradburn, Norman 1969

Carp, Frances M. 1974

Cooley, Charles Horton 1902
The Social Construction of Reality, Garden City, New York: Doubleday \& Company.

"Women, Marriage, and the Future," The Futurist, Apri1, Vol. IV, No. 2, pp. 41-43.

"Society as Symbolic Interaction," in Manis, Jerome, and Bernard Meltzer, eds., Symbolic Interaction: A Reader in Social Psychology, Boston: Allyn and Bacon, pp. 179-192.

"The Six Stations of Divorce" in Bohannan, Paul, ed., Divorce and After, Garden City, N.Y.: Doubleday and Company, Inc. pp. 29-55.

"Mate Selection as the Development of a Relationship," Journal of Marriage and Family Living, Vol. 23, No. 3, August, pp. 234-240.

Family and Social Network, London: Tavistock Publications.

The Structure of Psychological Well-Being, Chicago, Aldine Publishing Company.

"Position Effects on Interview Responses," Journal of Gerentology, Vol. 29, No. 5, pp. 581-587.

Human Nature and the Social Order, New York: Charles Scribner \& Sons. 
Foote, Nelson N. and Leonard S. Cottrell 1955

Identity and Interpersonal Competence, Chicago: The University of Chicago Press.

Glaser, Barney" G. and Anse1m Strauss 1965 Awareness of Dying, Chicago: Aldine Publishing Co.

Glaser, Barney G. and Anselm Strauss 1967

The Discovery of Grounded Theory, Chicago: Aldine Publishing Company.

Goode, Nflliam J. 1956

After Divorce (Renamed Women in Divorce), New York: The Free Press.

Goode, William $\mathrm{J}$, and Paul K. Hatt 1952

Methods in Social Research, New York: McGraw-Hill Book Company, Inc.

Goffman, Erving 1959

The Presentation of Self in Everyday Life, Doubleday \& Company.

Helper, Malcolm 1955

"Learning Theory and the Self-Concept," Journal of Abnormal and Social Psychology, Vol. 51, No. 2, Sept., pp. 184-194.

Kinch, John $\mathrm{N}$. 1963

"A Formalized Theory of the Self-Concept," in Manis, Jerome G. and Bernard N. Meltzer, eds., Symbolic Interaction: A Reader in Social Psychology, pp. 232-240.

Libby, Roger $W$. and Robert $v$. Whitehurst 1973

Renovating Marriage, Dannville, Cal.: Consensus Publishers.

Maccoby, Eleanor E. and Nathan Maccoby 1954

"The Interview: A Tool of Social Science," in Lindzey, Gardner, ed., Ilandbook of Social Psychology, Vol. I, Reading, Mass.: Addison-Tesley, pp. 449-487.

Manis, Melvin 1955

"Social Interaction and the Self Concept," Journal of Abnormal and Social Psychology, Yo1. 51, No. 3, No. v pp. 362-370.

Mead, George H. 1934

Mind, Self and Society, Chicago: The University of Chicago Press. 
Miller, Arthur A. 1970

"Reactions of Friends to Divorce," in Bohannan, Paul, ed., Divorce and After, pp. 56-77.

Miyamoto, S.F. and S.M. Dornbusch 1956

"A Test of Interactionist Hypothesis of Self Conception," AJS, Vo1. IXI, No. 5, March, pp. 399403.

Schwartz, Pepper 1973

"Female Sexuality and Monogamy," in Libby, Roger and Robert Whitehurts, eds., Renovating Marriage, pp. 211-226.

Sherif, Nuzafer 1936

The Psychology of Social Norms, New York: Harper and Brothers.

Thomas, William I. 1931

"The Definition of the Situation," in Manis, Jerome, and Bernard Meltzer, eds., Symbolic Interaction: A Reader in Social Psychology, pp. 315-321.

Videbeck, Richard 1960

"Self-Conception and the Reactions of Others," in Manis, Jerome and Bernard Meltzer, eds. Symbolic Interaction: A Reader in Social Psychology, pp. 279-287.

Waller, Willard and Reuben Hill 1938

"The Process of Alienation," in Heiss, Jerold, ed., Family Roles and Interaction: An Anthology, Chicago: Rand McNaIIy \& Co., 1968, pp. 483-500. 